\title{
Article \\ UAV-Based Remote Sensing for Managing Alaskan Native Heritage Landscapes in the Yukon-Kuskokwim Delta
}

\author{
Jonathan S. Lim $^{1, * \mathbb{D}}$, Sean Gleason ${ }^{2}$, Meta Williams ${ }^{3}$, Gonzalo J. Linares Matás ${ }^{1} \mathbb{D}$, Daniel Marsden ${ }^{2}$ \\ and Warren Jones 4 \\ 1 School of Archaeology, University of Oxford, 1 South Parks Rd., Oxford OX1 3TG, UK; \\ gonzalo.linaresmatas@st-hughs.ox.ac.uk \\ 2 Department of Rhetoric, Hampden-Sydney College, 172 Via Sacra, Hampden Sydney, VA 23901, USA; \\ sgleason@hsc.edu (S.G.); marsdend23@hsc.edu (D.M.) \\ 3 Alaska Christian College, 35109 Royal Pl, Soldotna, AK 99669, USA; mwilliams21@alaskacc.edu \\ 4 Qanirtuuq Inc., 100 Qanirtuuq Dr., Quinhagak, AK 99655, USA; wjones@qanirtuuq.com \\ * Correspondence: jonathan.lim@arch.ox.ac.uk
}

check for updates

Citation: Lim, J.S.; Gleason, S.; Williams, M.; Linares Matás, G.J.; Marsden, D.; Jones, W. UAV-Based Remote Sensing for Managing Alaskan Native Heritage Landscapes in the Yukon-Kuskokwim Delta. Remote Sens. 2022, 14, 728. https://doi.org/10.3390/rs14030728 Academic Editors: Jan Brus and Vilém Pechanec

Received: 29 December 2021 Accepted: 2 February 2022 Published: 4 February 2022 Publisher's Note: MDPI stays neutral with regard to jurisdictional claims in published maps and institutional affiliations.

Copyright: (c) 2022 by the authors. Licensee MDPI, Basel, Switzerland. This article is an open access article distributed under the terms and conditions of the Creative Commons Attribution (CC BY) license (https:// creativecommons.org/licenses/by/ $4.0 /)$.

\begin{abstract}
The Yukon-Kuskokwim (Y-K) Delta is home to the Alaskan Native Yup'ik people who have inhabited this remote, subarctic tundra for over 1500 years. Today, their ancestral lifeways and cultural landscapes are at risk from severe climate change-related threats. In turn, we propose that remote sensing technologies, particularly with sensors mounted on Unmanned Aerial Vehicle (UAV) platforms, are uniquely suited for protecting Yup'ik landscape heritage. Based on collaborative, community-based fieldwork in Quinhagak, AK, we present evidence that cultural sites—ranging from historic fishing camps to pre-contact winter villages-exhibit predictably atypical vegetation patterns based on the local ecological biome. Furthermore, these vegetation patterns can be recorded and statistically quantified through the analysis of multispectral imagery obtained from UAV-mounted sensors with three different false color composite rasters and vegetation indices depending on biome type. Finally, we suggest how the Yupiit can combine these methodologies/workflows with local knowledge to monitor the broader heritage landscape in the face of climate change.
\end{abstract}

Keywords: UAV remote sensing; Alaska; archaeology; ethnobotany; multispectral imagery; vegetation indices; capacity building; climate change; subsistence; traditional land use area

\section{Introduction}

\subsection{Landscapes in Flux and Heritage at Risk}

The Yukon-Kuskokwim (Y-K) Delta is an expansive, windswept tract of subarctic tundra in southwestern Alaska containing wetlands, lakes, and salmon-bearing rivers (Figure 1). As a deltaic environment, it is characterized by high morphological variation and change due to seasonal cycles of fluvial deposition and erosion [1]. In an era of unprecedented climate change, however, such changes pose an immediate, existential threat to the Alaskan Native Yup'ik people (pl. Yupiit) who have called this landscape home for the past 1500 years [2-6]. In particular, the reduction of permafrost levels and sea-ice along the Bering Sea coast, when combined with increased frequency and intensity of coastal storms, has led to the rapid degradation of coastlines and waterways [1,7]. In response, many coastal Yup'ik communities have begun planning for relocation further inland, and one such village, Newtok, has already been evacuated due to catastrophic levels of erosion [8]. 


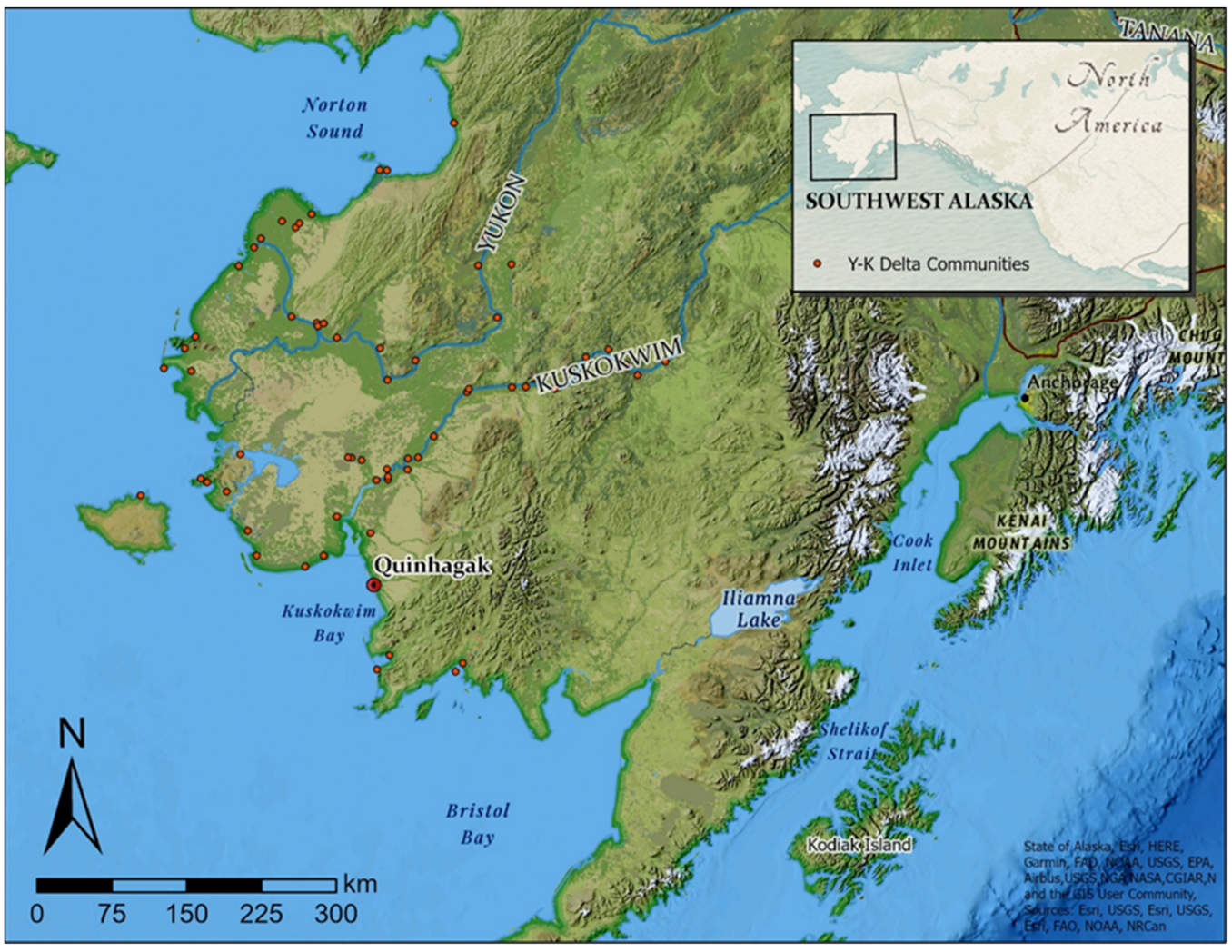

Figure 1. The Yukon-Kuskokwim Delta, where the major salmon-bearing Yukon and Kuskokwim rivers flow into the Bering Sea, is home to 52 Yup'ik communities in Southwest Alaska.

As Yup'ik villages in the Y-K Delta consolidate, they leave behind ancestral subsistence sites, fish camps, and winter villages passed down over generations. As a result, recent decades have seen a concerted effort by the Yupiit to reclaim their heritage, culture, history, and language through close collaboration with archaeological projects and materials [3,9-12]. There is also a sentiment prevalent in many communities that Elder knowledge in the form of Qanruyutet (trans. "wise words for living") will help future Yupiit navigate a rapidly changing world [13-15]. In response, we introduce new remote sensing techniques for the Y-K Delta by combining automated UAV multispectral surveys, machine learning, vegetation sampling, and ethnographic inquiry about subsistence activities known collectively as Yuuyaraq (trans. "Our way of life") to monitor and assess Yup'ik material heritage in a broader cultural landscape under threat from climate change. Our results suggest that heritage sites near coastal Yup'ik villages can be detected and characterized relative to distinct vegetation signatures occurring within the landscape ecology. In turn, we suggest a workflow and protocol for the comparative use of different visualization techniques for remote sensing across the different biomes in the Y-K Delta.

\subsection{Remote Sensing Strategies in the Y-K Delta: Satellites vs. Drones}

Remote sensing refers to the automated collection of environmental data using either sensors in orbit or those mounted to Unmanned Aerial Vehicles (UAV's, also known colloquially as "drones") [16]. With the emergence of higher quality and more easily-accessible satellite imagery, remote sensing has gained traction for use in rural and environmentally severe regions elsewhere in the world [17-19]. In Alaska, multispectral satellite imagery has been used to locate archaeological features in southwestern Alaska based on localized vegetation differences caused by past human activity [20]. For these reasons, we believe that remote sensing is a powerful, cost-effective tool for Alaskan Native communities to efficiently locate and manage cultural subsistence sites and local ecologies by reducing the necessity for costly, time-consuming, and potentially dangerous ground surveys [21]. 
Satellite-based approaches, however, are not without limitations: The highest quality imagery available for civilian use has a true spatial resolution of $30 \mathrm{~cm}$, which fails to delineate smaller cultural features or associated changes in vegetation. Satellite imagery is also useless in unfavorable environmental conditions and sensor configurations including cloud cover, haze, and overly off-nadir sensor angles [16]. Moreover, compared to lowerlatitude regions, there is less regular coverage of the circumpolar arctic, so satellites must be "tasked" to acquire legible imagery-a process that offsets the benefits of using satellites given the high costs for researchers [22]. Fortunately, these limitations might be addressed through the deployment of UAVs. While civilian models have a limited operating range and must be launched in the vicinity of the study area by an operator, they can be programmed with autonomous flight paths to enable the remote capture of imagery over large swathes of terrain with a range of different sensors [23]. When flying at a low altitude, UAVs also avoid cloud cover and capture imagery with a higher resolution than satellite-based sensors.

Case studies from elsewhere in the circumpolar Arctic have demonstrated how UAVs have assisted heritage researchers in harsh environments with a remote sensing platform that is affordable, versatile, and customizable due to swappable sensor payloads [24-28]. Ecological research in other cold climates has also benefited from the use of UAV technology [29]. Moreover, for UAV-based surveys of vegetation growth around cultural sites, the high resolution afforded by low-altitude flights allows researchers to spatially identify smaller plant communities, clusters, and their associated heritage features [25]. Finally, the observation of vegetation changes in aerial imagery as an indicator of past human activity is a well-established technique [30]. However, its use in the context of pre-colonial sites in southwest Alaska is limited due to the nature of the cultural remains-They are often hard to locate, as they have a small visible footprint, and are constructed from the same material as the surroundings [20]. A common example would be the ubiquitous pre-contact "sod house", a semi-subterranean sod-built structure found at abandoned winter village sites and old subsistence camps [9]. We contend that this limitation is alleviated by UAVs, which can obtain imagery at a low altitude of a quality far better than satellite-based techniques. Importantly, this increased resolution and visual clarity provides researchers the opportunity to consult local populations to help interpret heritage data [31,32]. For these reasons, our proposed methodology utilizes UAV-based surveys to provide a cheap, readily available solution for other Alaskan Native communities who are interested in conducting subsistence-based management surveys in the face of remote site locations, limited infrastructure, and hazardous environmental conditions.

\section{Materials and Methods}

\subsection{Data and Study Area: Quinhagak, AK}

Quinhagak is a Yup'ik village (pop. 700) located at the mouth of the Qanirtuuq (var. Kanektok) river on the Bering Sea (Figure 2). Since 2009, the village-in partnership with archaeologists from the University of Aberdeen-has led archaeological excavations at Nunalleq (GDN-248), a c. 17th-century ancestral winter village [11]. This communitybased project has culminated in the establishment of a heritage museum in the village to house over 100,000 artifacts recovered from the site and a renewed interest in precontact subsistence traditions across the broader ecological landscape [11,33-35]. In turn, an international research team has worked alongside Yup'ik community members in recent years to preserve and combine Yup'ik science with emerging technologies to help document and understand the complex seasonal networks of movement that have characterized Yup'ik subsistence for over 1500 years.

While Nunalleq is a preeminent archeological site for understanding the historical relationship between Yupiit and their environment, it represents a narrow glimpse into a larger network of subsistence sites that are still in use today: For millennia Yup'ik in the Y-K Delta have relied on specialized ecological knowledge passed down through successive generations to harvest fish, game, and edible plants in an annual, subsistence cycle from thaw to frost $[9,36]$. Beginning in the spring, as the ice floes begin to break up along the 
Bering Sea, Yupiit travel to seasonal hunting grounds located near marshy in-land lakes to hunt and trap numerous bird species including ptarmigan, speckled duck, and cormorant. By midsummer, the salmon season is underway in earnest at intergenerational fish camps where families work to filet, hang, and cure their catch on split-beam fish racks. During this time, families also take to the tundra on all-terrain vehicles (known colloquially as 'Hondas') to harvest berries, wild grains, and edible greens including sour dock [15]. August ushers in driving rains and winds throughout the Y-K Delta that mark the end of silver salmon season and the beginning of fall trapping and big game hunting, which occurs at higher elevations near the mountains. Historically, families would habitually move from summer fish camps to hunting grounds further in-land while in the cooler months, villages would shelter at ancestral winter sites consisting of large semi-subterranean sod houses (Enet) arranged in concentric circles around a communal men's house known as a Qasiq/Qasqi [9]. Within this heritage landscape, many of these ancestral winter villages contained archaeological remains (e.g., fish-processing pits, food caches, and sod homes) that still saw use until the mid-20th century [37].

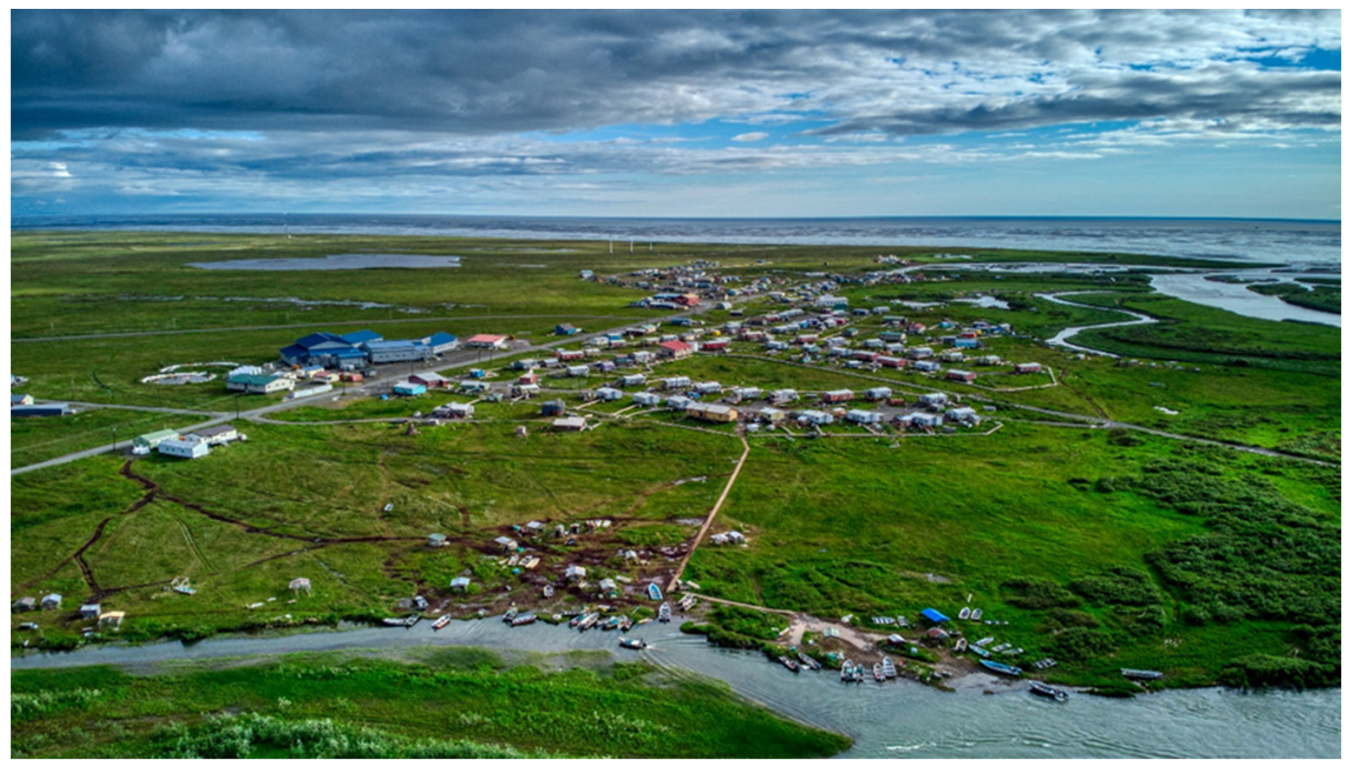

Figure 2. Quinhagak, a Yup'ik community of 700 people by the Bering Sea. UAV photo by authors, facing west.

It is within this larger network of subsistence, travel, and specialized ecological knowledge that individual sites, like Nunalleq, exist today in the collective cultural landscape known as a Traditional Land Use Area (TLUA). Like many other communities in the Y-K Delta, Quinhagak's TLUA is described through the use of traditional place names in the Yup'ik language of Yugtun that, in turn, encode environmental knowledge and oral histories within the landscape $[13,20]$. In large part, the specificity afforded by Yup'ik place names is a consequence of the postbasing (i.e., agglutinative) nature of Yugtun, which allows speakers to string together numerous qualifiers and cases into a single word to provide additional context. For example, a camping site containing dry ground, tall grass species, and a source of fresh drinking water may contain descriptive elements strung together in a compound word such as Qavartaqeryaraq (trans. "place where one may safely camp overnight"), Meqsarturyaraq (trans. "place where we get fresh water") or Angyarrairyaraq (trans. "the place where boats can barely get through") [38]. Although these place names are often overlooked in the official state or federal mapping projects, the history, location, and continued existence of these sites remain vital to Yup'ik culture and subsistence (i.e., Yuuyaraq). Here, remote sensing provides a cheap, reliable means to monitor sites on behalf of local land managers who may not be able to visit sites to inspect potential changes given the size of many TLUAs in the Y-K Delta. Moreover, the 
village of Quinhagak represents an ideal location to test new methodologies regarding the detection and classification of ancestral sites using automated UAV multispectral surveys given both the size of its TLUA (185,000 acres) and the history of community-based research surrounding the Nunalleq project.

\subsection{Study Sites Selection}

The Quinhagak subsistence area contains over 231 traditional place name sites distributed along 185,000 square acres along the salmon-bearing rivers of Qanirtuuq (var. Kanektok), Agalig (var. Arolik), and Uyak river systems (Figure 3). As a result of the 1971 Alaska Native Claims Settlement Act (ANSCA), Yup'ik villages in the Y-K Delta are organized into regional corporations where land is either administered by village corporate leadership or subdivided into individual native allotments that are federally administered and passed down from generation to generation [39]. Thus, any remote sensing conducted on behalf of, or alongside Alaskan Native communities must be undertaken with express consent from village allotment owners and/or village corporations. In Quinhagak, 33 of the 231 recorded traditional place names are located on ANCSA 14(h) private allotments owned by individual landowners.

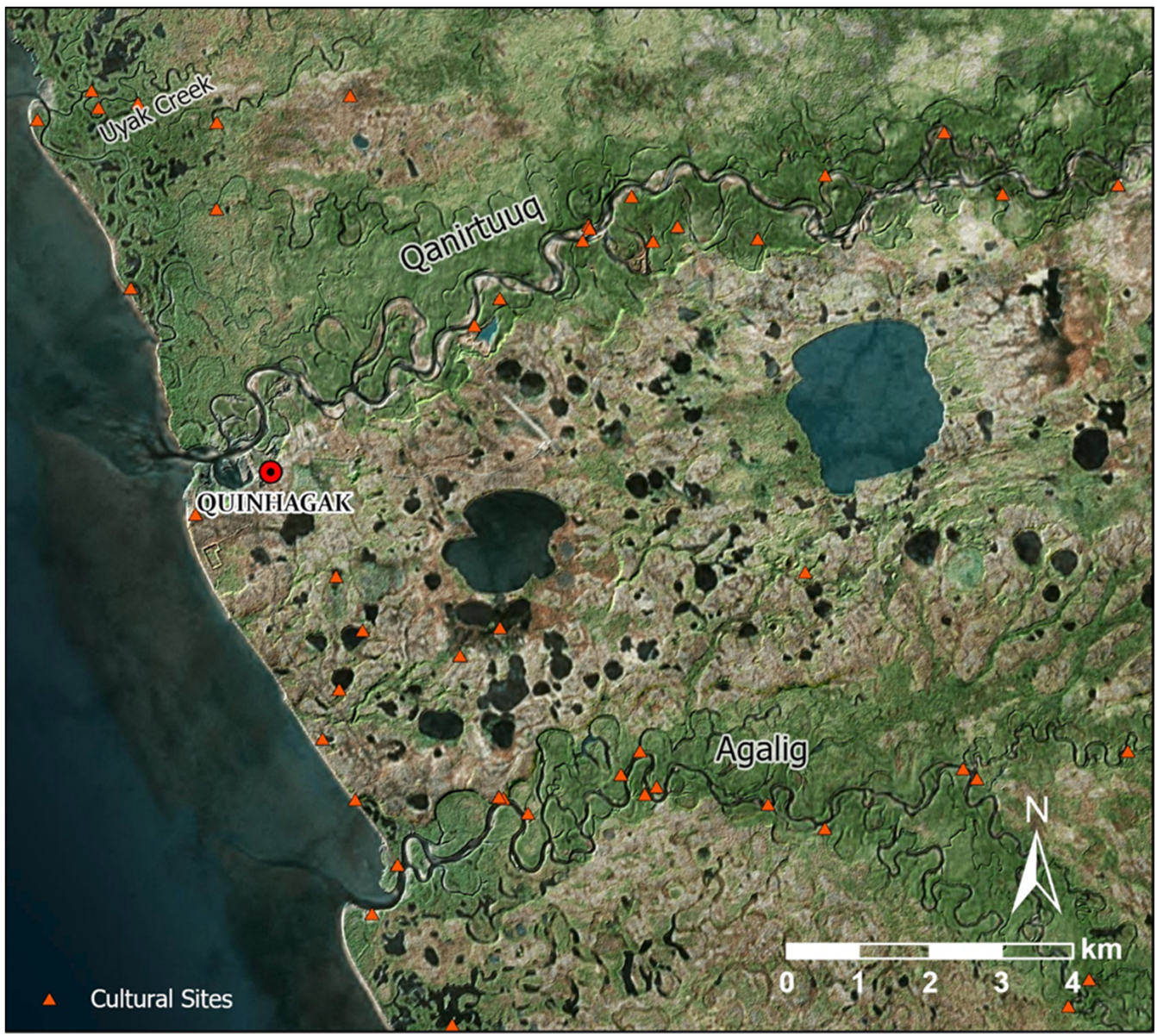

Figure 3. Distribution of cultural sites with traditional place names around Quinhagak. Note the concentration along the major waterways of the Qanirtuuq and Agalig rivers.

Given these parameters, the first step in site selection was to work with the local Land Manager's office in Quinhagak to digitize existing traditional place names and ANCSA 14(h) allotment maps and geo-reference known heritage sites in ArcGIS 2.9 This information was then submitted to Quinhagak's ANCSA village corporation Qanirtuuq Inc. for review in June of 2019. Next, researchers met with current and former land managers, Elders, and Qanirtuuq Inc. leadership to select a subset of sites containing archaeological features that 
were most at risk for climate change. From these interviews and community meetings, approximately 30 sites were selected as "high risk" given their proximity to coastlines, riverbanks, or other erosion threats.

From 2019-2020 researchers conducted preliminary site visits at 14 of the "high risk" sites after gaining explicit permission from Qanirtuuq Inc. (Quinhagak) and ANCSA 14 (h) allotment owners. During these site visits a combination of on-site interviewing, preliminary vegetation assessment, archaeological test-pitting, and visual drone surveys were conducted to verify site location, known archaeological features, and classify the site according to traditional use. Data collected during site visits were also used to conduct structured and semi-structured interviews with community members who had the ability to choose between English and Yugtun for the duration of the interview. Recorded interviews focused primarily on community site usage, recent erosion events, and Elder knowledge regarding site location and change. In particular, researchers made use of digital maps that combined drone footage (.mp4, .jpg), GIS layers (.shp), and A/V material (.braw, .wav) from site visits (Figure 4 ).

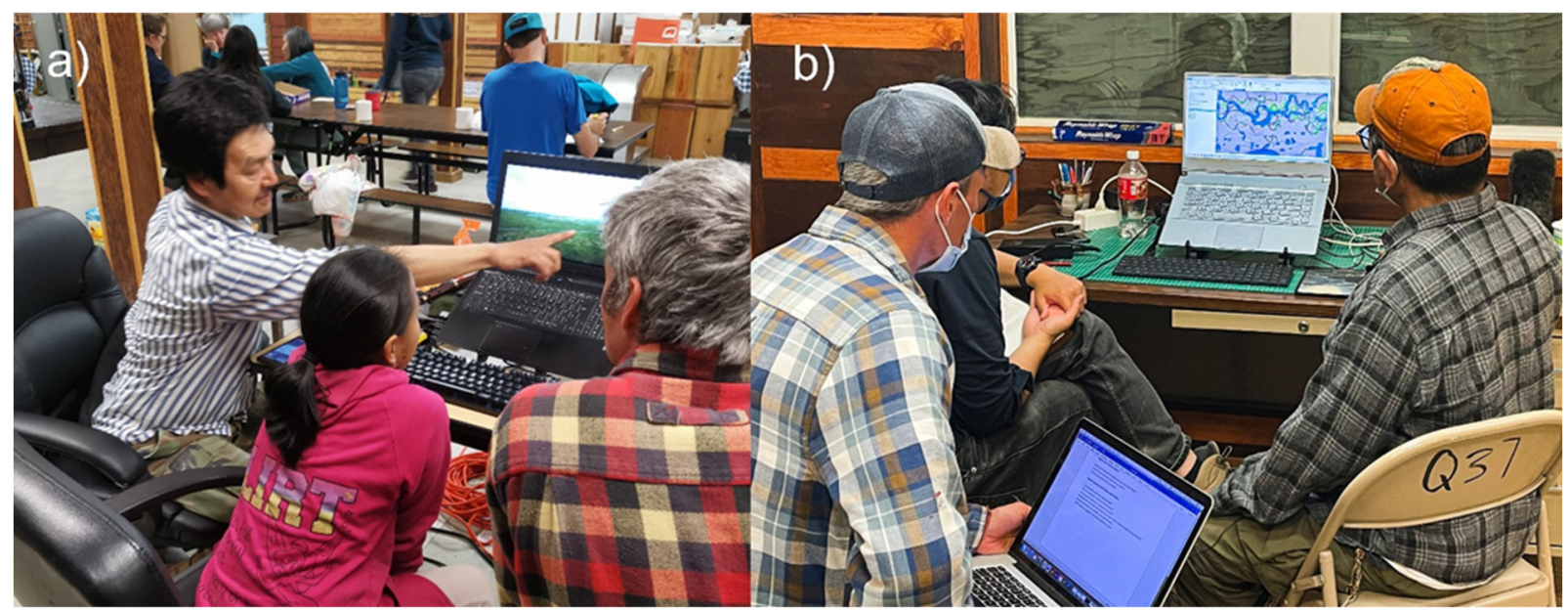

Figure 4. Ethnographic interviews combined conventional techniques with drone footage and GISbased maps to help clarify features of Quinhagak's TLUA. (a) Quinhagak resident John Foster reviews drone footage of the Qanirtuuq River in June of 2019 (photo credit: Anna Mossolova). (b) Former Qanirtuuq Corp. Land Manager Joseph Pleasant reviews a GIS map of heritage sites along the Agalik river during a recorded interview in July of 2021 (photo credit: Daniel Marsden).

Recorded interviews were archived via an audio/video screen capture of ESRI (Redlands, California) ArcGIS Pro 2.9 (.mp4) and cardioid lavalier microphones (.wav). Next, the audio/video files were combined in Adobe Premiere Pro, and a reference timecode was generated. The interview was then thematically coded with a table of contents and section titles when appropriate. Minimal edits were made to eliminate occasional verbal fillers and help clarify content when more than one individual spoke at the same time. Oral consent was gathered at the beginning and end of each interview and any photos, artifacts, and manuscripts donated during an interview were copied and archived in a passwordprotected electronic database. Finally, all recorded interviews were transcribed, and copies of all $\mathrm{A} / \mathrm{V}$ material were sent to collaborators so that individuals had the ability to edit, redact, or add additional information as needed.

This combination of preliminary site visits and ethnographic inquiry played a vital role in the final selection of sites for analysis. For instance, ethnographic inquiry helped establish which ancestral sites are still in use today through intergenerational prefixes for certain sites including ak'arpak (trans., "forever/since long ago) [2,40]. In other cases, unstructured interviews with Quinhagak community members during site visits helped establish the biome classification system used to delineate different types of tundra (e.g., "hard tundra" vs. sphagnum moss) or provided additional knowledge about specific indicator species 
typically found at ancestral sites (e.g., cilqaaq, Chamerion angustifolium). Together these ethnographic protocols allowed researchers to select a stratified, representative sample of known sites that (1) included typical archeological features (e.g., fish pits or sod houses) that had been "ground truthed" via test-pitting, (2) were located along major riverways or coastal areas, (3) contained adequate local knowledge about site usage, and (4) occurred in one of the three primary biome types where archaeological sites are found in Quinhagak's TLUA. Biome 1a seems to occur on well-drained tundra at relatively high elevations, consisting of equal parts lichen and grass. Where there are visible surface indications of archaeological material, like abandoned sod structures or fish processing pits, there is often a dense concentration of forbs, especially cilqaaq (Fireweed, Chamerion angustifolium), a forb with purple flowers. Conversely, Biome $1 \mathrm{~b}$ is so named because it tends to occur at similar elevations as Biome 1a but is less well-drained, and with a 60/40 ratio of lichen to grass. Dense patches of salmonberry (Rubus chamaemorus) grow on the remains of former habitation structures in this biome. Biome 2 can be found in poorly drained, low-lying deltaic areas overwhelmingly dominated by graminoids. Surficial archaeological features are covered with grass that is noticeably taller and of a darker green-yellow hue than that of the surroundings. The presence of atypical vegetation patterns on cultural sites is a well-known phenomenon in southwest Alaska and may be explained by soil enrichment through food processing or waste activities, or soil compaction by past humans [20]—such patterns may therefore be said to be anthropogenically derived.

From this list of eight sites, one representative site $(n=3)$ was selected from each biome type for further analysis (see Table 1).

Table 1. Known cultural sites near Quinhagak with confirmed surficial archaeological features and their corresponding biome type. Note the predictable vegetation pattern around features based on biome type. Sites names denoted with "** are focus sites-they were surveyed with the UAV and will be discussed at length below.

\begin{tabular}{|c|c|c|c|c|}
\hline $\begin{array}{l}\text { Biome } \\
\text { Type }\end{array}$ & $\begin{array}{l}\text { Tundra Biome } \\
\text { Description }\end{array}$ & Site Name & Site Description & $\begin{array}{c}\text { Anomalous } \\
\text { Vegetation Patterns }\end{array}$ \\
\hline \multirow{3}{*}{$1 \mathrm{a}$} & \multirow{3}{*}{$\begin{array}{l}\text { Well-drained tundra at } \\
\text { relatively high elevations. } \\
\text { The dominant natural } \\
\text { vegetation consists of equal } \\
\text { parts lichen and grass. } \\
\text { Surficial archaeological } \\
\text { features display dense } \\
\text { growth of forbs, especially } \\
\text { cilqaaq (Fireweed, } \\
\text { Chamerion angustifolium), } \\
\text { a forb with purple flowers. }\end{array}$} & Tengluk (GDN-268) * & $\begin{array}{l}\text { Terrace of a former lake at the } \\
\text { mouth of the Qanirtuuq with } \\
\text { clusters of fish processing pits. It } \\
\text { is known ethnographically as } \\
\text { being the fish camp of the Carter } \\
\text { family sometime in the mid-20th } \\
\text { century ([38] Annie Cleveland } \\
\text { pers comm. 16/7/2019) }\end{array}$ & $\begin{array}{l}\text { Dense community of } \\
\text { cilqaaq (Fireweed, } \\
\text { Chamerion angustifolium) } \\
\text { around the largest } \\
\text { cluster of pits. }\end{array}$ \\
\hline & & GDN-267 & $\begin{array}{l}\text { A large sod house with two } \\
\text { smaller sod structures. } \\
\text { Typologically prehistoric Yup'ik } \\
\text { artifacts were recovered from the } \\
\text { sod house and a radiocarbon } \\
\text { date on a worked antler tool is } \\
\text { pending. It is probably broadly } \\
\text { contemporary with the } \\
\text { Nunalleq site. }\end{array}$ & $\begin{array}{l}\text { Dense community of } \\
\text { cilqaaq in the vicinity of } \\
\text { the sod structures. }\end{array}$ \\
\hline & & Agalig Grave & $\begin{array}{l}\text { A } 9 \text { m long oval grave mound on } \\
\text { a river terrace near the Agalig } \\
\text { mouth of indeterminate age. } \\
\text { Oral histories suggest it belongs } \\
\text { to a man who did not listen to } \\
\text { his Elders and was swept away } \\
\text { by a strong current. His body } \\
\text { was found entangled in branches } \\
\text { upriver days later (Grace } \\
\text { Annover pers. Comm. 2021) }\end{array}$ & $\begin{array}{c}\text { Dense community of } \\
70 \% \text { unidentified forbs } \\
\text { and } 30 \% \text { cilqaaq } \\
\text { growing on the grave } \\
\text { mound. }\end{array}$ \\
\hline
\end{tabular}


Table 1. Cont.

\begin{tabular}{|c|c|c|c|c|}
\hline $\begin{array}{l}\text { Biome } \\
\text { Type }\end{array}$ & $\begin{array}{l}\text { Tundra Biome } \\
\text { Description }\end{array}$ & Site Name & Site Description & $\begin{array}{c}\text { Anomalous } \\
\text { Vegetation Patterns }\end{array}$ \\
\hline \multirow[t]{2}{*}{$1 b$} & \multirow[t]{2}{*}{$\begin{array}{l}\text { Very closely related to } \\
\text { biome type 1a, but less } \\
\text { well-drained. Lichen and } \\
\text { grass are still dominant, } \\
\text { but with an approximately } \\
60 / 40 \text { ratio. Very complex } \\
\text { biome, with the highest } \\
\text { variety of plant species. } \\
\text { Surficial archaeological } \\
\text { features are covered with } \\
\text { lichen and dominated by } \\
\text { salmonberry plants } \\
\text { (Rubus chamaemorus) }\end{array}$} & Nunalleq (GDN-247) * & $\begin{array}{l}\text { A large prehistoric sod house } \\
\text { complex that has been extensively } \\
\text { excavated and damaged by } \\
\text { erosion. A single large } 15 \mathrm{~m} \\
\text { unexcavated sod house is present } \\
30 \mathrm{~m} \text { southeast from the main } \\
\text { excavation trench. A test pit in the } \\
\text { middle of this structure from } 2017 \\
\text { shows a probable habitation } \\
\text { context } 1 \mathrm{~m} \text { below the surface. } \\
\text { A worked antler from here yields } \\
\text { a radiocarbon date of } 220 \pm 30 \text { cal. } \\
\text { BP, making it contemporaneous } \\
\text { with the terminal phase of the } \\
\text { Nunalleq site. }\end{array}$ & $\begin{array}{l}\text { Very dense tall grass } \\
\text { community on the } \\
\text { excavation trench of the } \\
\text { main site. The walls of } \\
\text { an unexcavated } \\
\text { collapsed structure are } \\
\text { now covered with } \\
\text { lichen and dominated } \\
\text { by salmonberry plants } \\
\text { (Rubus chamaemorus). }\end{array}$ \\
\hline & & $\begin{array}{c}\text { Sam Carter's Fish } \\
\text { Camp }\end{array}$ & $\begin{array}{l}\text { The former site of late Elder Sam } \\
\text { Carter's fish camp where he lived } \\
\text { for most of the year, on a river } \\
\text { terrace overlooking the Agalig. } \\
\text { There was reportedly a single sod } \\
\text { house there while he was still } \\
\text { alive in the 1970s, but its exact } \\
\text { location is unknown (John Smith } \\
\text { pers. Comm. 2021). A subsurface } \\
\text { grave on the terrace edge was } \\
\text { observed eroding into the Agalig } \\
\text { in } 2017 \text { by the author, but it is } \\
\text { unclear if this grave belonged to } \\
\text { Sam Carter or an ancestor. }\end{array}$ & $\begin{array}{l}\text { Possible earthworks are } \\
\text { potentially the } \\
\text { remnants of two sod } \\
\text { structures, now } \\
\text { dominated by } \\
\text { salmonberry plants. }\end{array}$ \\
\hline
\end{tabular}

An apparent "Old Village" site with four sod houses at a creek north of Quinhagak. Artifacts, including lithics, have been eroding from the two houses at the creek bank for many years. Looter pits are present, corresponding to ethnographic accounts of looting [Church pers comm 2021]. An artifact eroding from the structure has been dated to Cal AD 1450 to 1640 [Knecht pers. Comm.]

At least three sod houses are present. One is eroding into the bay at the mouth of the Agalig. Protohistoric (ie. 19th century) artifacts have been recovered, like an ornate wooden spoon. The rate of erosion is rapid at this site.

A historic Yup'ik settlement that was abandoned in the early 20th century. The site of the settlement is recorded in oral

Agaligamiut (GDN-010) histories and a 1956 USGS map.

No evidence of habitation structures is visible to investigators doing ground surveys. However, a cluster of fish processing pits is present.
On the structures themselves grows grass of a darker, more yellow hue that is much taller than the surrounding grass.

On the structures themselves grows grass of a darker, yellower hue that is much taller than the surrounding grass.

Vegetation color differences are present at the location of the former settlement but are only visible through analysis of multispectral satellite imagery [20]. A cluster of probable

fish processing pits grows grass of a darker, more green-yellow hue that is much taller than the surrounding grass. 


\subsection{Image Capture: Equipment, Software, and Procedures}

For each of the three sites selected for analysis, the imagery was captured with a Parrot Sequoia+ multispectral camera mounted on a DJI Phantom 3 Advanced UAV via an integration kit manufactured by MicaSense(Seattle, USA). The Sequoia+ has five separate sensors: One that produces composite Red-Green-Blue (RGB) imagery and four additional monochrome sensors that measure reflectance in two visible (Green: 530-570 nm, Red: 640-680 nm) and non-visible (Red-Edge: 730-740 nm, Near-Infrared: 770-810 nm) bands. Next, a flight plan for each site was generated in Aeroscientific's DJI Flight Planner with the built-in Google Maps satellite imagery base map for reference. Care was taken to ensure that all UAV flights would capture imagery with an $80 \%$ flight strip overlap and very high ground sampling distances (GSD, $<8 \mathrm{~cm}$ ) (Table 2). Parrot Sequoia+ camera packages are normally equipped with a "sunshine sensor", which serves to standardize reflectance values of any imagery obtained-this allows researchers to readily compare values between imagery obtained from different surveys with variable ambient light conditions. Unfortunately, the sunshine sensor used in this study was damaged in the field, making it difficult to calibrate the reflectance of imagery between sites. However, the lack of a functioning sunshine sensor did not preclude the analysis of vegetation patterns from the same site (as described in Section 2.5), as the imagery for each site was captured over the span of 15-20 min where ambient light levels were unlikely to change. Indeed, the authors discarded and re-executed four surveys where the ambient light levels did change quickly over the survey period, particularly on windy days where a large cloud noticeably obscured the sun while the UAV was collecting imagery.

Table 2. The area surveyed of each site and resolution of imagery.

\begin{tabular}{cccc}
\hline Site & Monochrome G.S.D. & RGB G.S.D. & Area Surveyed \\
\hline Nunalleq & $4.5 \mathrm{~cm}$ & $1.3 \mathrm{~cm}$ & $33,871.93 \mathrm{~m}^{2}$ \\
\hline Tengluk & $4.4 \mathrm{~cm}$ & $1.2 \mathrm{~cm}$ & $48,022.77 \mathrm{~m}^{2}$ \\
\hline Uyakmiut & $5.2 \mathrm{~cm}$ & $1.7 \mathrm{~cm}$ & $37,500.88 \mathrm{~m}^{2}$ \\
\hline
\end{tabular}

Flight paths were then imported into the Litchi app on an Android phone, which was used to control the UAV for takeoffs/landings and execute the automated flight plan. After establishing five to six Ground Control Points (GCPs) for each site, the geometric extent of the survey (or survey "footprint") of each site was exported as a .kml file to be opened in ArcGIS Pro 2.9. Using the survey footprint for reference, GCPs were then manually digitized for each site within ArcGIS Pro in the NAD 1983 (2011) Alaska Albers map projection. Finally, GCPs were exported to a Reach RS+ differential global navigation satellite system (dGNSS) unit which was used to prominently mark GCP location in the field with fluorescent orange spray paint.

\subsection{Ethnobotanical and Archaeological Ground Surveys}

At the conclusion of each UAV flight, the extent of known archaeological features was recorded with a dGNSS unit based on the physical surface remains of structures, past archeological surveys, and test-pitting when necessary to establish the boundaries of a given feature. For each site, vegetation cover on archeological features was documented with researchers recording dominant species heights (min, mean, and max), density, and distribution within the context. For each context, photographs and samples of abundant plant species were also collected so that species distribution and prevalence could be corroborated by Yupiit familiar with each site.

For the Nunalleq site, an additional ethnobotanical survey was conducted given that the site is also a contemporary subsistence location for gathering berries, sedge grasses, and other traditional-use plants. These ethnobotanical surveys were carried out in conjunction with Meta Williams, a Quinhagak local with knowledge of the traditional uses of plant 
species in the Y-K Delta. Here, Williams had access to Fienup-Riordan's recent work, "Yungcautnguuq Nunam Qainga Tamarmi/The Entire Surface of the Land is Medicine: Edible and Medicinal Plants of Southwest Alaska" [41] as a reference while carrying out this survey (Figure 5). Working closely with Williams, and in conjunction with UAV imagery, the Nunalleq environs were classified into sections based on the communities of vegetation present (Table 3).

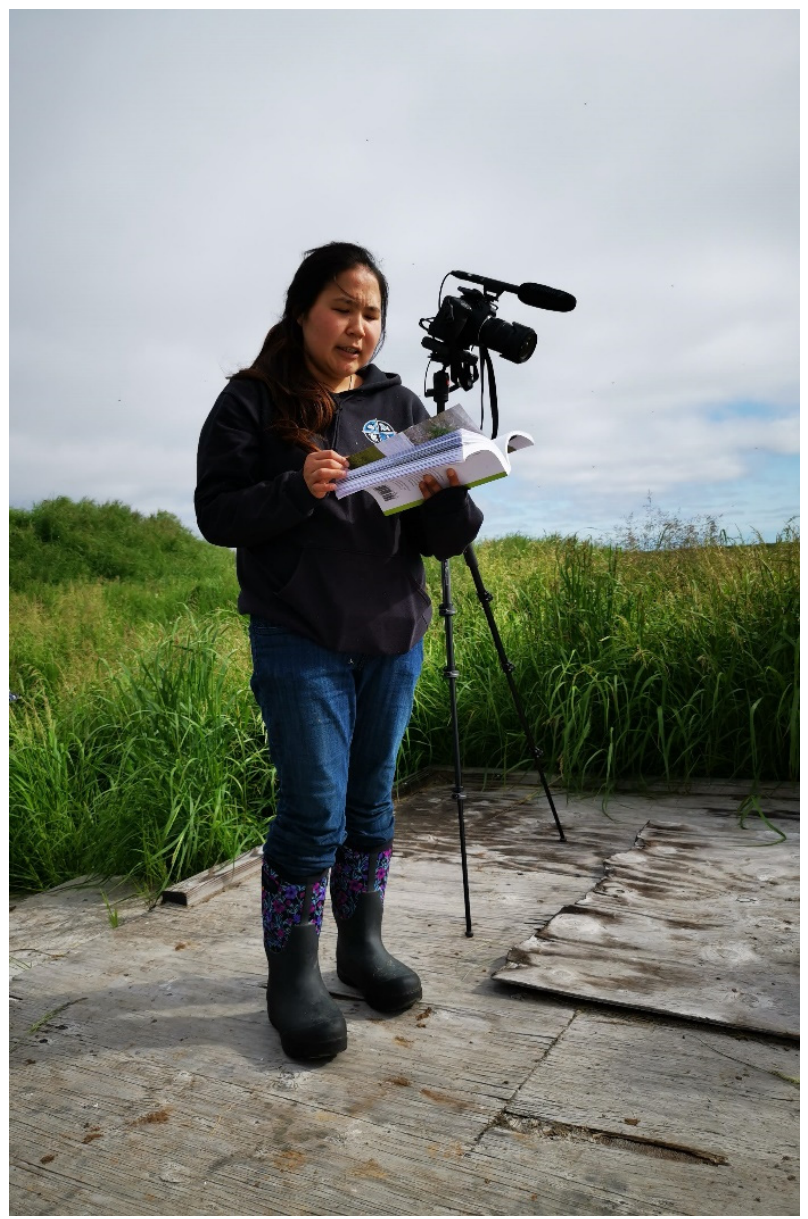

Figure 5. Meta Williams identifying edible and utilitarian plants around the Nunalleq site.

Table 3. The following subregions of vegetation patterns visible on the ground were delineated alongside community member Meta Williams (See Figure $6 c$ for map).

\begin{tabular}{|c|c|}
\hline Vegetation Class & Description \\
\hline Tall Grass & $\begin{array}{l}\text { The site of the Nunalleq excavation trench and spoil heaps, which has not been excavated since } 2018 \text {, is densely } \\
\text { packed with tall tundra grass which is the dominant species present. Occasionally there are isolated pockets of } \\
\text { edible plants, notably Ikiitut (wild celery, Angelica lucida), which can be peeled like domesticated celery and is } \\
\text { traditionally eaten with seal oil. It also has medicinal properties as a pain relief agent and can be burned to } \\
\text { ward off mosquitoes [41]. Rye grass of the genus Lolium was also present, a source of basket-weaving material } \\
\text { for past and present Yupiit. This vegetation pattern is normally present at the edge of the erosion face of the } \\
\text { bank with the beach, extending inland about } 1.5-3 \mathrm{~m} \text {, or along small creeks as they flow into the Bering Sea. } \\
\text { However, only at the localized area of the Nunalleq site does the vegetation stretch } 20 \mathrm{~m} \text { inland. }\end{array}$ \\
\hline Berry & $\begin{array}{l}\text { A dense patch of atsalugpiat (salmonberry, Rubus chamaemorus) occurs on a bed of lichen on the top of } \\
\text { an unexcavated sod house. Atsalugpiat is the most important subsistence berry for the Yupiit in Alaska, as } \\
\text { an ingredient in akutaq ("Eskimo ice-cream"), and the leaves are reported to have healing qualities [41]. They } \\
\text { bloom and ripen over a two-week window in late July. Infrequently, small patches of curat (blueberries, } \\
\text { Vaccinium uliginosum) were also present. }\end{array}$ \\
\hline
\end{tabular}


Table 3. Cont.

\begin{tabular}{cc}
\hline Vegetation Class & Description \\
\hline & $\begin{array}{c}\text { Adjacent to Class } 1 \text { is an intermediary area. It is poorly drained but has a rich variety of edible and medicinal } \\
\text { floral species, like occasional salmonberries, blackberries, and Ayuq (abrador tea, Rhododendron tomentosum) } \\
\text { plants. The word Ayuq is derived from the verb post-base ayu-, which means "to spread"-this refers to its } \\
\text { ability to "carry away" illness when consumed as a tea [41]. There is also an abundance of Melquruat (white } \\
\text { cottongrass (Eriophorum scheuchzer) and Russet cottongrass (Eriophorum russeolum)) which may be boiled to } \\
\text { form a poultice for the treatment of cuts and boils. They are also a traditional indicator species-an abundance } \\
\text { of Melquruat can predict an abundance of salmonberry later in the summer. Patches of dried cottongrass } \\
\text { throughout this area are signs of communal vole burrow complexes. These are often sources of yet another } \\
\text { important subsistence resource, colloquially known as "mouse food". Voles cache several different edible roots } \\
\text { and tubers in their burrows, which are harvested by the Yupiit to supplement their diet. }\end{array}$ \\
\hline Lichen & $\begin{array}{r}\text { The normal inland vegetation for this biome type. It is poorly drained and consists roughly of } 60 \% \text { lichen and } \\
40 \% \text { grass. }\end{array}$ \\
\hline Beach & A beach with fine grey-black silty sand. This area is sparsely vegetated with rare, isolated tufts of sedge grass. \\
\hline
\end{tabular}

\subsection{Data Processing and Spectral Analysis}

After the multispectral imagery was captured, individual stills were combined into orthomosaics in Agisoft Metashape 1.7.4, and then stacked into a four-band orthomosaic raster. This raster was imported into ArcGIS Pro 2.9 for further analysis. A Normalized Difference Vegetation Index (NDVI) of the raster was calculated to highlight vegetation vigor since NDVI is an index with an established track record of use for archaeological applications. However, it was found to be inefficient at delineating vegetation changes. Consequently, several other indices were attempted, and two were identified as better alternatives to NDVI: Red Edge NDVI (NDVIre), and Green Chlorophyll Index (Cig) (Table 4).

Table 4. Three vegetation indices were tested in this study to measure their ability to visually and statistically delineate vegetation changes.

\begin{tabular}{ccc}
\hline Index Name & Formula & Description \\
\hline $\begin{array}{c}\text { Normalized Difference } \\
\text { Vegetation Index (NDVI) } \\
\text { [42] }\end{array}$ & NDVI $=\frac{\text { NIR-Red }}{\text { NIR }+ \text { Red }}$ & $\begin{array}{c}\text { The most established vegetation index; } \\
\text { it is in use across a variety of disciplines } \\
\text { and applications, such as archaeology, } \\
\text { ecology, and agriculture. }\end{array}$ \\
\hline $\begin{array}{c}\text { Red Edge NDVI (NDVIre) } \\
\text { [43] }\end{array}$ & NDVIre $=\frac{\text { NIR-RedEdge }}{\text { NIR+RedEdge }}$ & $\begin{array}{c}\text { A variation of NDVI that uses the Red } \\
\text { Edge band rather than Red for } \\
\text { calculating vegetation vigor. It is used in } \\
\text { agriculture for estimating crop health } \\
\text { during the mid-late stages of its life cycle. }\end{array}$ \\
\hline $\begin{array}{c}\text { Green Chlorophyll Index } \\
\text { (Cig) }\end{array}$ & CIg $=\frac{\text { NIR }}{\text { Green-1 }}$ & $\begin{array}{c}\text { An index used in agriculture to } \\
\text { estimate chlorophyll content in leaves. }\end{array}$ \\
\hline 44$]$
\end{tabular}

Next, a segmented raster was calculated for the orthomosaic of each site in ArcGIS Pro 2.9 for visual inspection and statistical analysis. The segmentation groups pixels together and removes unnecessary outliers in the data that might skew the results. The segmentation process uses only three out of the four available bands, and ESRI documentation recommends using the three bands that display the greatest ability to discriminate the features of interest. These combinations were thus selected through visual inspection of each individual band: For Tengluk and Nunalleq (Biome Type 1a and b), the Red-RE-NIR bands were used to build the segmented raster, and for Uyakmiut (Type 2) the Green-RedNIR bands were used. Finally, the most superficial level of segmentation was utilized as the Spectral and Spatial Details settings were set at 20 (out of a maximum of 20). This 
was done to reduce spectral value outliers while still retaining data regarding individual plant communities.

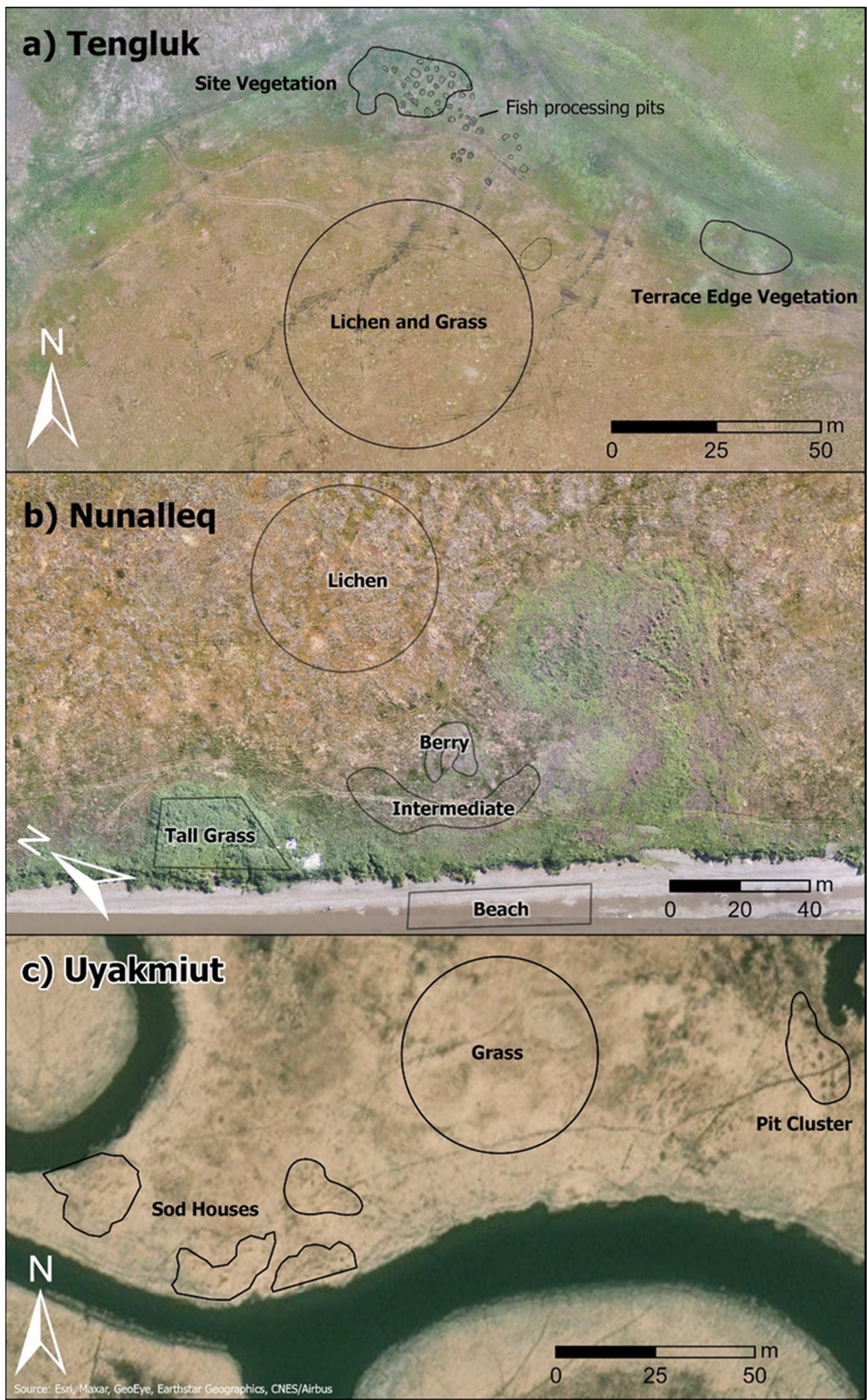

Figure 6. The zones that were used for sampling spectral values were based on known archeological features and dominant vegetation present at each focussite of (a) Tengluk, (b) Nunalleq, and (c) Uyakmiut. For the Nunalleq site only (b), an ethnobotanical survey with local Yup'ik collaborator Meta Williams was used to help define these zones. 
Open high-resolution satellite imagery from ESRI Living Atlas was used as a base map to help verify the accuracy of the control points taken in the field and to illustrate the relatively high quality of imagery obtained from UAVs (Metadata for the imagery is available, allowing us to identify the specifications for the sensor that captured it).

Discrete zones in each site were then selected and digitized as polygons in ArcGIS Pro 2.9 based on the presence of cultural remains and visible vegetation differences (Figure 6). Subsequently, random points were generated within each polygon (the number of points being determined by Polygon Area $\times 10$ ) to produce tables of index values for each of the three vegetation index rasters (Table 5). Next, each table of values was analyzed in the IBM (Armonk, NY, USA) SPSS Statistics 28.0 software package to determine which visualization technique best discriminates between anthropogenically-derived vegetation differences and natural local vegetation. Since all values for each index exhibited a non-parametric distribution, each table was subjected to the Kruskal-Wallis test to determine whether the medians of each zone were statistically distinct [45].

Table 5. The number of sampling points, proportional to the size of the zone.

\begin{tabular}{|c|c|c|}
\hline \multirow{4}{*}{ Uyakmiut } & Class & Points sampled \\
\hline & Sod House & 1832 \\
\hline & Pit Cluster & 2680 \\
\hline & Grass & 19,149 \\
\hline \multirow{5}{*}{ Nunalleq } & Tall Grass & 6251 \\
\hline & Berry & 1605 \\
\hline & Beach & 5686 \\
\hline & Intermediate & 5358 \\
\hline & Lichen & 24,474 \\
\hline \multirow{3}{*}{ Tengluk } & Site Vegetation & 3257 \\
\hline & Terrace Edge Vegetation & 1930 \\
\hline & Lichen and Grass & 27,703 \\
\hline
\end{tabular}

To help group spatially distinct vegetation patterns, Principal Components Analysis (PCA) was also conducted on the composite rasters in Rstudio using the FactoMineR library [46]. PCA is a useful dimensionality reduction technique that minimizes redundancy while preserving most variation-inducing information within a dataset $[47,48]$. PCA is often used in exploratory data analysis to quantify Euclidean distances between two or more vegetation classes. For each site, PCA graphs were generated using ggfortify [49], an ancillary package of ggplot2. The vectors shown in the resulting graphs are the eigenvectors of the covariance matrix scaled by the square root of the corresponding eigenvalue and provide a visual reference about how each variable influences data point distribution within the PCA space.

Using the PCA data, the significance of within-sample differences and similarities were assessed by applying a non-parametric Pairwise Permutation Multiple Variance Analysis (MANOVA) with a $p$-value $<0.001$ (Permutations $=999$ ) using the RVAideMemoire package. Lastly, Linear Discriminant Analysis (LDA), a pattern recognition technique optimized for class separability was conducted on the dataset using the MASS and caret packages in R-Studio [50-52]. The resulting confusion matrix enabled an evaluation of group classification accuracy, where classification errors were greatest between the most closely related subsamples (Table 6). We note the consistency between LDA confusion matrix evaluations and the degree of group overlap in the PCA graphs. 
Table 6. Confusion matrices stemming from the Linear Discriminant Analysis machine learning algorithm, enabled us to assess and quantify the classification accuracy associated with the data employed to generate the PCA graphs.

\begin{tabular}{|c|c|c|c|c|c|c|}
\hline \multirow{6}{*}{ Uyakmiut } & & Sod House & Pit Cluster & Grass & & \\
\hline & Sod House & 707 & 2 & 415 & & \\
\hline & Pit Cluster & 74 & 1969 & 314 & & \\
\hline & Grass & 1047 & 705 & 18,420 & & \\
\hline & Total & 1828 & 2676 & 19,149 & & \\
\hline & Balanced Accuracy & 0.68383 & 0.85865 & 0.7865 & & \\
\hline \multirow{8}{*}{ Nunalleq } & & Tall Grass & Berry & Beach & Inter. & Lichen \\
\hline & Tall Grass & 5288 & 65 & 0 & 231 & 11 \\
\hline & Berry & 4 & 345 & 0 & 18 & 50 \\
\hline & Beach & 0 & 0 & 5681 & 0 & 209 \\
\hline & Intermediate & 955 & 463 & 0 & 3451 & 704 \\
\hline & Lichen & 4 & 722 & 5 & 1645 & 21,500 \\
\hline & Total & 6251 & 1595 & 5686 & 5345 & 22,474 \\
\hline & Balanced Accuracy & 0.9186 & 0.607245 & 0.9966 & 0.79336 & 0.9154 \\
\hline \multirow{6}{*}{ Tengluk } & & Site Vegetation & $\begin{array}{c}\text { Terrace Edge } \\
\text { Vegetation }\end{array}$ & $\begin{array}{c}\text { Lichen and } \\
\text { Grass }\end{array}$ & & \\
\hline & Site Vegetation & 2496 & 172 & 14 & & \\
\hline & $\begin{array}{l}\text { Terrace Edge } \\
\text { Vegetation }\end{array}$ & 371 & 1309 & 228 & & \\
\hline & Lichen and Grass & 379 & 448 & 27,461 & & \\
\hline & Total & 3246 & 1929 & 27,703 & & \\
\hline & Balanced Accuracy & 0.97516 & 0.97998 & 0.9157 & & \\
\hline
\end{tabular}

\section{Results}

\subsection{Tengluk (Type 1a Biomes)}

Tengluk is a fish processing site located on a former lake terrace near the mouth of the Qanirtuuq (var. Kanektok) River (Figures 7 and 8). As noted during ethnobotanical surveys, the fish pits at Tengluk are very heavily vegetated with cilqaaq (Fireweed, Chamerion angustifolium) in contrast to the surrounding tundra which is $50 \%$ grass and $50 \%$ lichen. This is notable because cilqaaq is known to grow at sites where the soil has been disturbed and is also found in dry tundra and grass-browse biomes (Griffin, 2009). Here, the NIRGreen-Red image was highly effective in delineating a spectrally distinct patch of fireweed within the larger cilqaaq community that was not apparent from the RGB imagery or ground survey. 


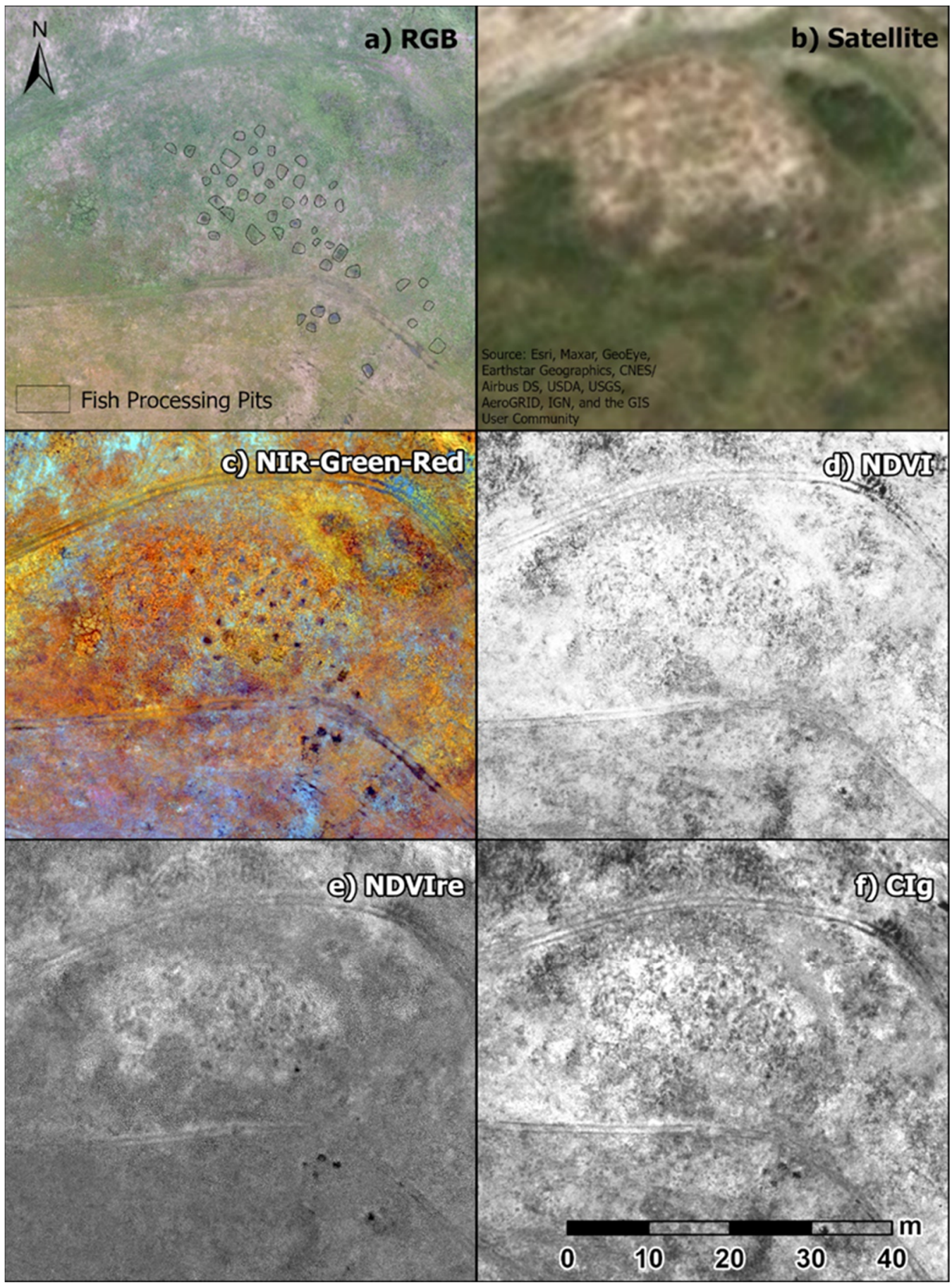

Figure 7. Visualizations of the Tengluk site. (a) UAV visible light aerial photograph showing outlines of fish processing pits. (b) $60 \mathrm{~cm}$ WorldView-02 (C) Maxar satellite imagery (c) The composite raster was highly effective at showing the pits themselves, along with the associated vegetation changes more so than the satellite imagery). (d) NDVI raster of the site, which shows poor discrimination between site and surrounding vegetation. Both (e) NDVIre and (f) Cig performed well, although the former was able to show the extent of cilqaaq growing on the site with less data noise than CIg. 


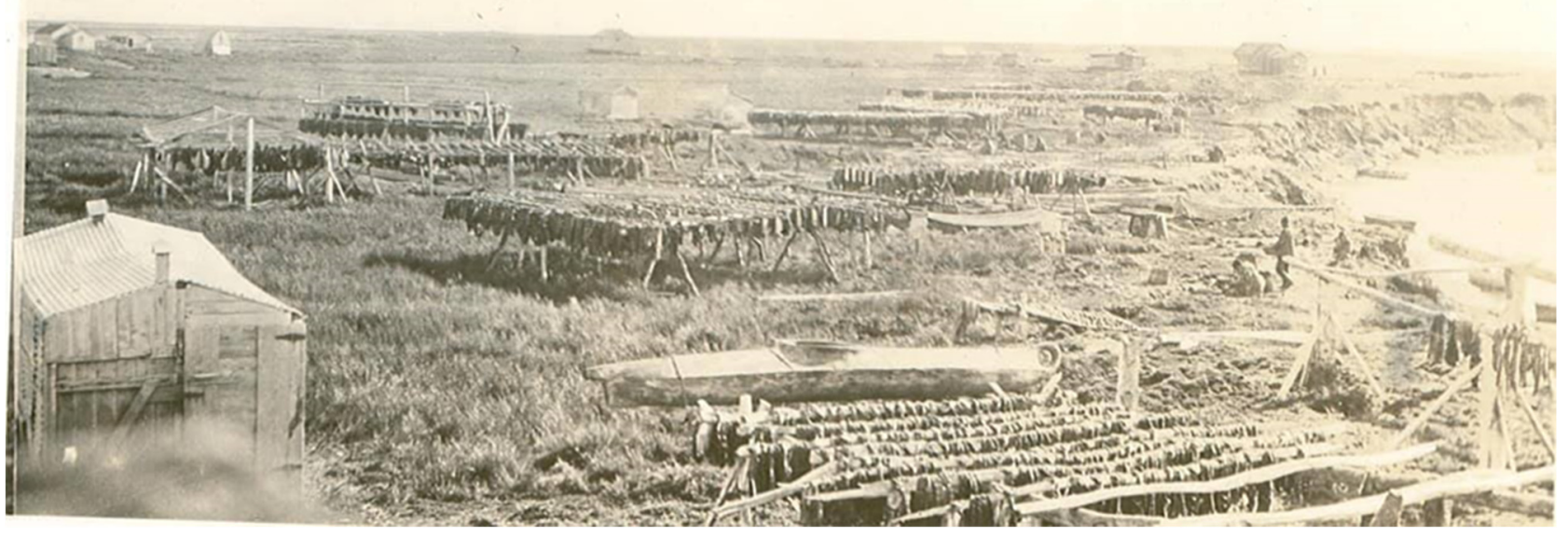

Figure 8. Possible photo of the Tengluk site in use in the early 20th-century, approximately where the person is crouched, surrounded by fish-drying racks. From [2], used with permission from Ann Fienup-Riordan, courtesy of Rhoda and Bill Thomas, and Chet Williams.

For visual inspection, the $1 \mathrm{mX} 1 \mathrm{~m}$ fish processing pits at Tengluk are clearest in the NIRGreen-Red false color composite. PCA analysis, however, shows that all three indices are successful at delineating between areas dominated by lichen and those with better-drained soil containing taller grasses (Figure 9). Here, NDVI did exceptionally well at producing a distinct spectral signature for lichen-dominated areas but was unable to discriminate between the terrace vegetation and the cilqaaq in terms of both Interquartile Range (IQR) overlap and Kruskal-Wallis Test significance values (Table 7). In contrast, Cig and NDVIre were more effective in characterizing the entire biome Figure 10). Between these two indices, NDVIre was best at distinguishing between the site vegetation and terrace edge vegetation, which is reflected in its comparatively better performance for visual analysis Figure 7. 
a)

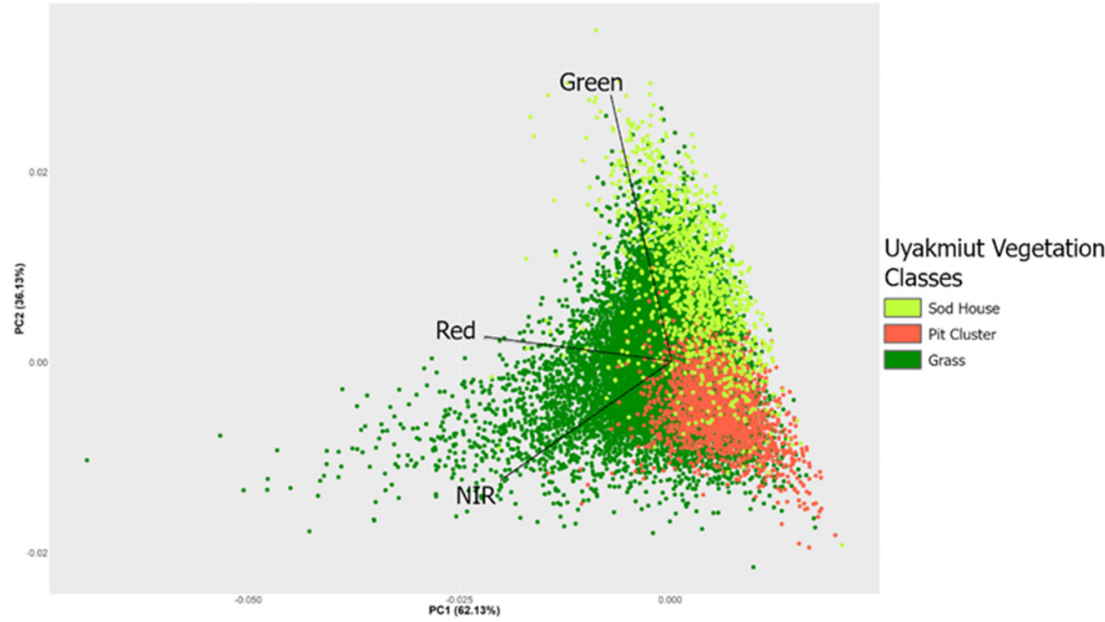

b)

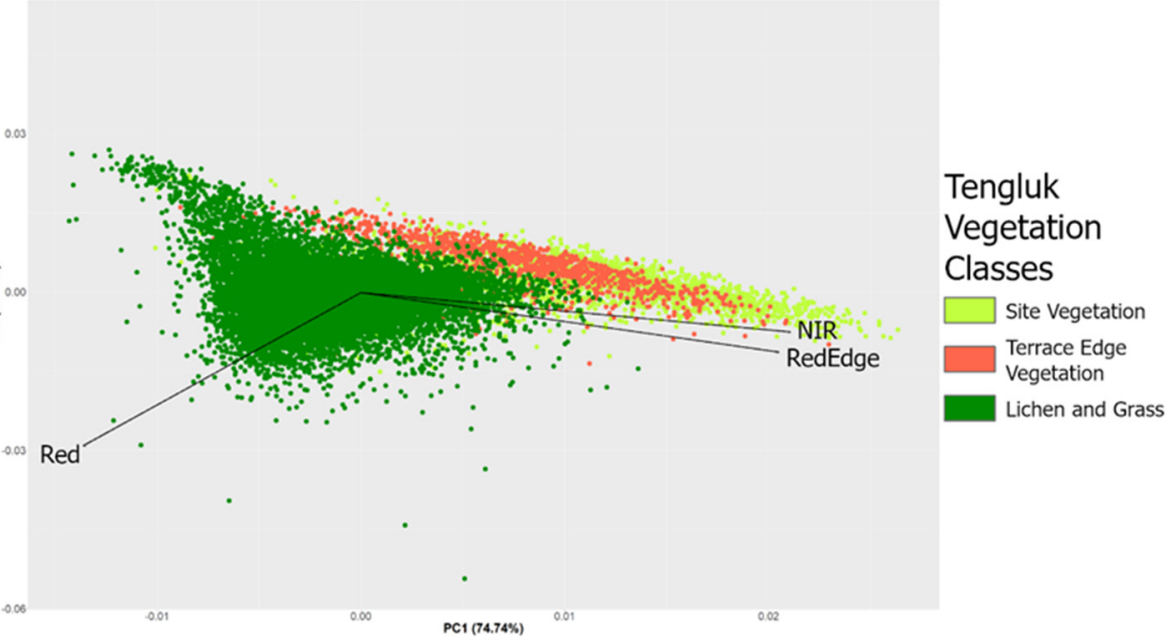

c)

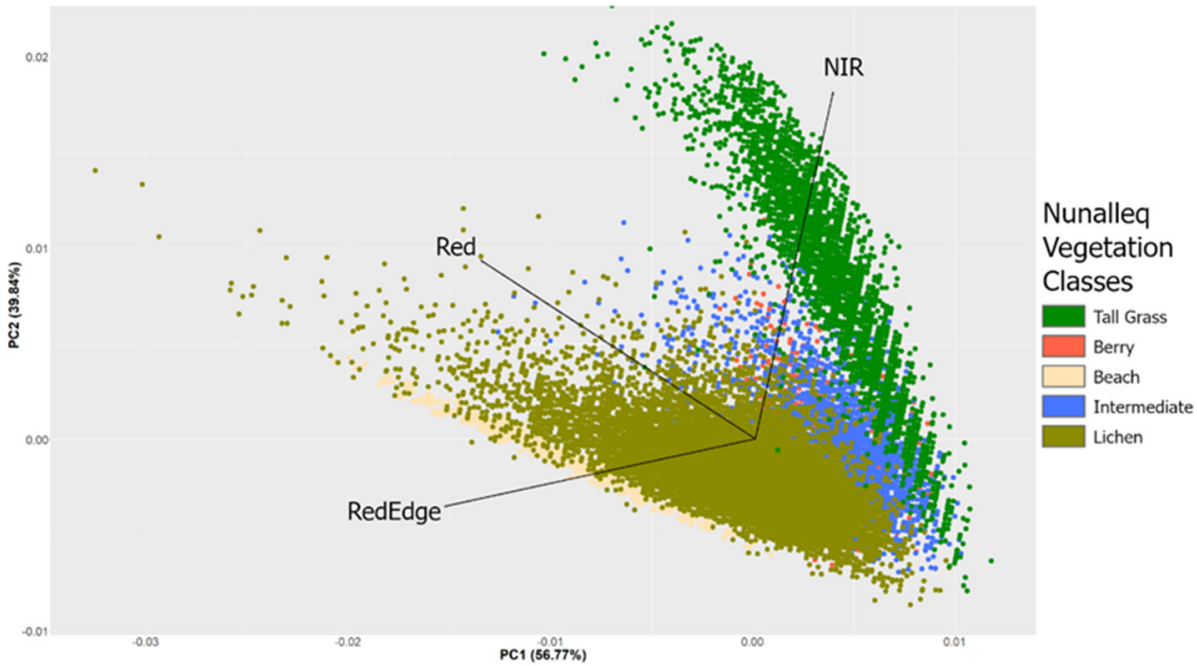

Figure 9. Spectral values PCA graphs of false color composite imagery from all three sites, where clustering of values indicates discrete spectral signatures. (a) At Uyakmiut, there were distinct clustering of values for vegetation related to past human activity, namely the vegetation around the pit cluster and sod house, despite the study area being dominated by a single species (b) Likewise, at Tengluk, the site vegetation around the pit clusters were distinct from the surrounding tundra, with slight overlap with the natural terrace edge vegetation (c) The spectral values of berries growing on the sod house at Nunalleq were dispersed despite being an indicator of past human activity. 
Table 7. Pairwise Comparisons of Vegetation Classes (Independent-Samples Kruskal-Wallis Test). On the sites tested, there are statistically significant differences between the spectral values of vegetation on cultural features. However, note that at Tengluk, NDVI was unable to distinguish between the vegetation around the fish processing pits and the surrounding terrace vegetation (See values in bold). Likewise, at Uyak, it failed to show statistical differences between the vegetation at the apparent pit cluster and the surrounding grass (See values in bold).

\begin{tabular}{|c|c|c|c|c|c|c|c|c|c|c|c|c|c|c|c|c|}
\hline & \multirow[b]{2}{*}{$\begin{array}{l}\text { Sample 1- } \\
\text { Sample } 2\end{array}$} & \multicolumn{15}{|c|}{$\begin{array}{l}\text { Pairwise Comparisons of Vegetation Classes (Independent-Samples Kruskal-Wallis Test) across Vegetation Indices Tested } \\
\text { NDVIre }\end{array}$} \\
\hline & & Test Statistic & Std. Error & $\begin{array}{l}\text { Std. Test } \\
\text { Statistic }\end{array}$ & Sig. & Adj. Sig. ${ }^{a}$ & Test Statistic & Std. Error & $\begin{array}{l}\text { Std. Test } \\
\text { Statistic }\end{array}$ & Sig. & Adj. Sig. ${ }^{a}$ & Test Statistic & Std. Error & $\begin{array}{l}\text { Std. Test } \\
\text { Statistic }\end{array}$ & Sig. & Adj. Sig. ${ }^{a}$ \\
\hline \multirow{8}{*}{ 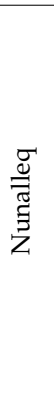 } & $\begin{array}{l}\text { Beach-Lichen } \\
\text { Beach-Berry }\end{array}$ & $\begin{array}{l}-14,698.572 \\
-23,974.871\end{array}$ & $\begin{array}{l}177.302 \\
338.418\end{array}$ & $\begin{array}{l}-82.901 \\
-70.844\end{array}$ & $\begin{array}{ll}0.000 \\
0.000\end{array}$ & $\begin{array}{ll}0.000 \\
0.000\end{array}$ & $\begin{array}{l}-13,360.581 \\
-15,431.148\end{array}$ & $\begin{array}{l}177.302 \\
338.418\end{array}$ & $\begin{array}{l}-75.355 \\
-45.598\end{array}$ & $\begin{array}{l}0.000 \\
0.000\end{array}$ & $\begin{array}{l}0.000 \\
0.000\end{array}$ & $\begin{array}{l}-15,002.918 \\
-19,920.298\end{array}$ & $\begin{array}{l}177.285 \\
338.385\end{array}$ & $\begin{array}{l}-84.626 \\
-58.869\end{array}$ & $\begin{array}{l}0.000 \\
0.000\end{array}$ & $\begin{array}{l}0.000 \\
0.000\end{array}$ \\
\hline & $\begin{array}{c}\text { Beach- } \\
\text { Intermediate }\end{array}$ & $-27,708.238$ & 227.548 & -121.769 & 0.000 & 0.000 & $-22,582.510$ & 227.548 & -99.243 & 0.000 & 0.000 & $-28,239.235$ & 227.525 & -124.115 & 0.000 & 0.000 \\
\hline & $\begin{array}{l}\text { Beach-Tall Grass } \\
\text { Lichen-Berry }\end{array}$ & $\begin{array}{c}-35,127.543 \\
9276.298\end{array}$ & $\begin{array}{l}218.883 \\
309.493\end{array}$ & $\begin{array}{l}-160.486 \\
29.973\end{array}$ & $\begin{array}{l}0.000 \\
0.000\end{array}$ & $\begin{array}{l}0.000 \\
0.000\end{array}$ & $\begin{array}{c}-32,534.868 \\
2070.567\end{array}$ & $\begin{array}{l}218.883 \\
309.493\end{array}$ & $\begin{array}{c}-148.641 \\
6.690\end{array}$ & $\begin{array}{l}0.000 \\
0.000\end{array}$ & $\begin{array}{l}0.000 \\
0.000\end{array}$ & $\begin{array}{c}-34,849.524 \\
4917.381\end{array}$ & $\begin{array}{l}218.861 \\
309.462\end{array}$ & $\begin{array}{l}-159.231 \\
15.890\end{array}$ & $\begin{array}{l}0.000 \\
0.000\end{array}$ & $\begin{array}{l}0.000 \\
0.000\end{array}$ \\
\hline & $\begin{array}{l}\text { Lichen- } \\
\text { Intermediate }\end{array}$ & $13,009.665$ & 181.760 & 71.576 & 0.000 & 0.000 & 9221.929 & 181.760 & 50.737 & 0.000 & 0.000 & $13,236.317$ & 181.742 & 72.830 & 0.000 & 0.000 \\
\hline & Lichen-Tall Grass & $-20,428.971$ & 170.788 & -119.616 & 0.000 & 0.000 & $-19,174.287$ & 170.788 & -112.270 & 0.000 & 0.000 & $-19,846.606$ & 170.771 & -116.218 & 0.000 & 0.000 \\
\hline & $\begin{array}{c}\text { Berry- } \\
\text { Intermediate }\end{array}$ & -3733.367 & 340.775 & -10.956 & 0.000 & 0.000 & -7151.362 & 340.775 & -20.986 & 0.000 & 0.000 & -8318.937 & 340.741 & -24.414 & 0.000 & 0.000 \\
\hline & Berry-Tall Grass & $-11,152.672$ & 335.051 & -33.286 & 0.000 & 0.000 & $-17,103.720$ & 335.051 & -51.048 & 0.000 & 0.000 & $-14,929.226$ & 335.018 & -44.562 & 0.000 & 0.000 \\
\hline & $\begin{array}{l}\text { Intermediate-Tall } \\
\text { Grass }\end{array}$ & -7419.305 & 222.509 & -33.344 & 0.000 & 0.000 & -9952.358 & 222.509 & -44.728 & 0.000 & 0.000 & -6610.289 & 222.487 & -29.711 & 0.000 & 0.000 \\
\hline \multirow{3}{*}{ 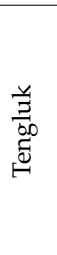 } & $\begin{array}{c}\text { Lichen and } \\
\text { Grass-Terrace } \\
\text { Edge Vegetation }\end{array}$ & $15,427.289$ & 223.579 & 69.002 & 0.000 & 0.000 & 7319.127 & 223.579 & 32.736 & 0.000 & 0.000 & $11,861.347$ & 223.579 & 53.052 & 0.000 & 0.000 \\
\hline & $\begin{array}{l}\text { Lichen and } \\
\text { Grass-Site } \\
\text { Vegetation }\end{array}$ & $15,454.333$ & 176.143 & 87.737 & 0.000 & 0.000 & $13,865.990$ & 176.143 & 78.720 & 0.000 & 0.000 & $14,137.207$ & 176.143 & 80.260 & 0.000 & 0.000 \\
\hline & $\begin{array}{c}\text { Terrace Edge } \\
\text { Vegetation-Site } \\
\text { Vegetation }\end{array}$ & 27.044 & 272.957 & 0.099 & 0.921 & 1.000 & 6546.863 & 272.957 & 23.985 & 0.000 & 0.000 & 2275.860 & 272.957 & 8.338 & 0.000 & 0.000 \\
\hline \multirow{2}{*}{ 节 } & $\begin{array}{l}\text { Pit Cluster-Sod } \\
\text { House }\end{array}$ & $-10,481.136$ & 195.932 & -53.494 & 0.000 & 0.000 & $-16,015.039$ & 195.932 & -81.738 & 0.000 & 0.000 & -2360.870 & 195.932 & -12.049 & 0.000 & 0.000 \\
\hline & Grass-Sod House & $-10,279.551$ & 113.749 & -90.370 & 0.000 & 0.000 & -9659.206 & 113.749 & -84.917 & 0.000 & 0.000 & $-10,251.875$ & 113.749 & -90.127 & 0.000 & 0.000 \\
\hline
\end{tabular}

Each row tests the null hypothesis that the Sample 1 and Sample 2 distributions are the
a Significance values have been adjusted by the Bonferroni correction for multiple tests. 
a)

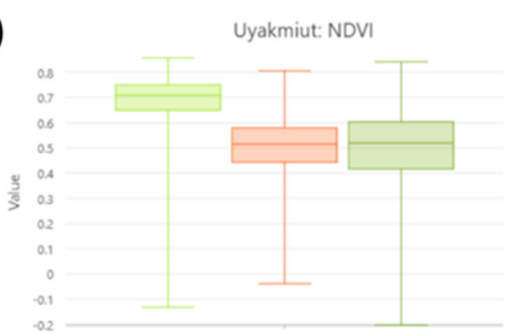

b)

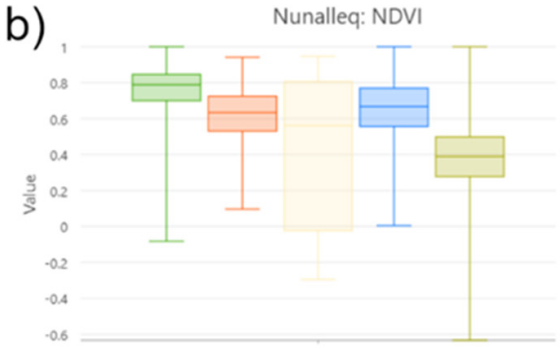

c)

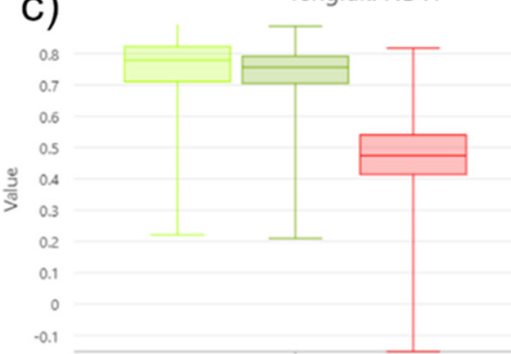

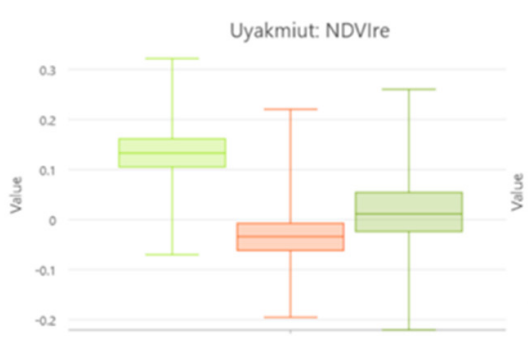
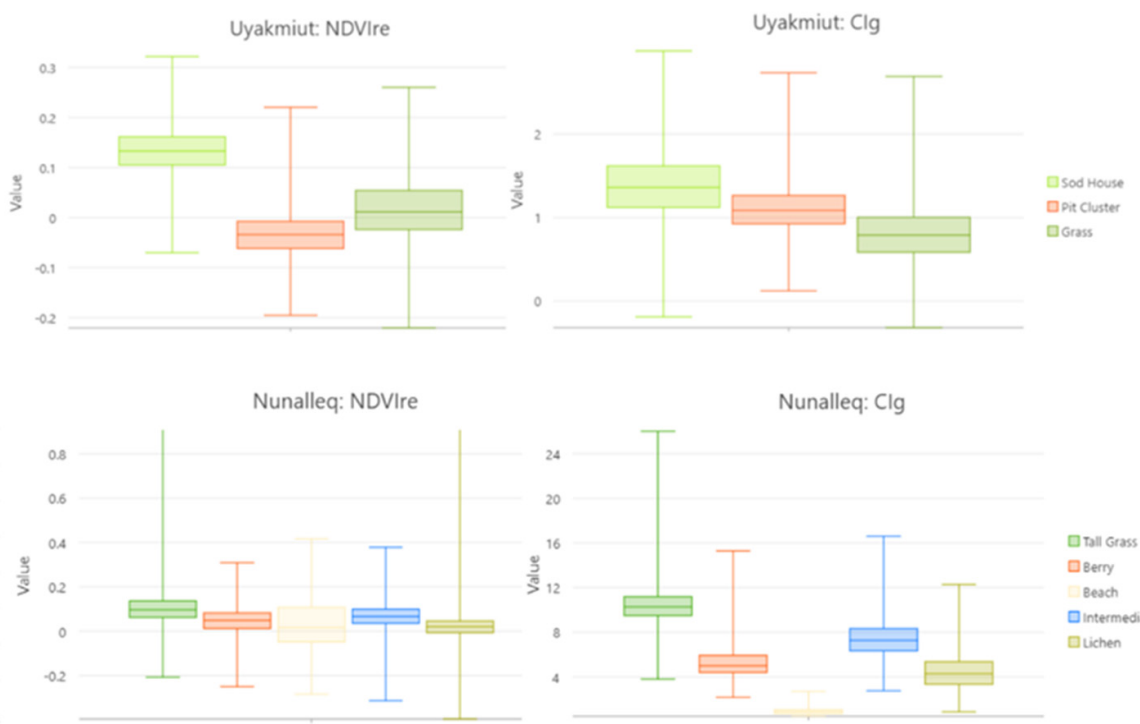

Nunalleq: $\mathrm{Clg}$
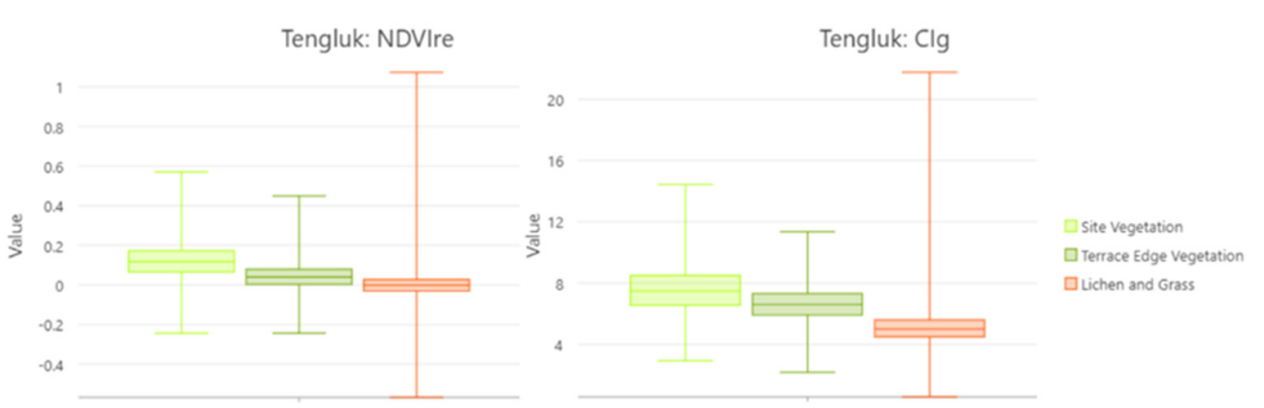

Figure 10. The non-overlap of interquartile ranges of different vegeation classes is a measure of efficiency for the single-band vegetation indices of (a) Uyakmiut, (b) Nunalleq, and (c) Tengluk.

\subsection{Nunalleq (Type $1 b$ Biomes)}

Nunalleq is a very complex and rich ecological environment with strong anthropogenicallyderived vegetation patterns. Around the main excavation trench, ten years of disturbance and deposition by archaeologists have exposed past habitation contexts that are enriched with organic material. As a result, the area surrounding the main excavation trench is dominated by tall grass species in an environment normally characterized by lichen. In contrast, the compacted sod remains of the unexcavated sod house are covered with lichen and a dense patch of salmonberry plants (Figure 11). Here, both the main excavation trench and unexcavated sod house are most pronounced in the false color NIR-Green-Red composite image.

At Nunalleq, once again, NDVI proved to be the least effective of the vegetation indices tested. Both NDVIre and Cig were very effective at delineating the main trench and unexcavated sod house, especially the latter, which produced a stronger tonal contrast between the unexcavated house and the surrounding tundra. In the PCA graph of the Red-RE-NIR there is strong discrimination between all classes except for the salmonberry patch growing on the unexcavated archaeological site, which is dispersed throughout the values of the well-defined Intermediate cluster (Figure 9). Unlike both NDVI and NDVIre, the Cig vegetation index accurately characterized the distinct spectral properties between all classes defined with the help of Meta Williams during TEK ethnobotanical surveys, albeit with a small amount of overlap in the IQR of Berry and Lichen (Figure 10). Overall, the $\mathrm{CIg}$ index was consistent with its good performance in the visual analysis in Figure 11. 


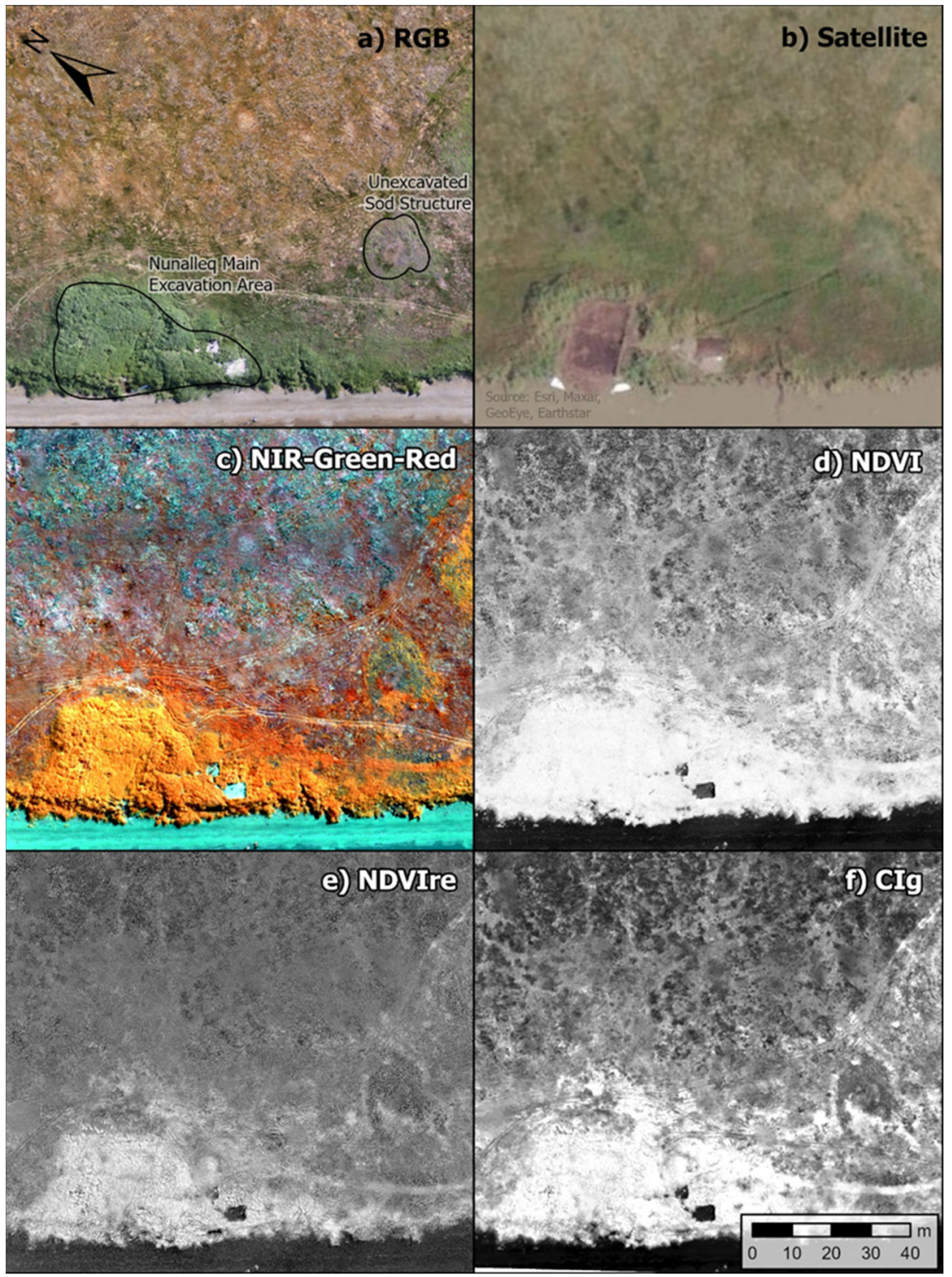

Figure 11. Visualizations of the Nunalleq site. (a) UAV aerial photograph of the Nunalleq site. Two distinct vegetation patterns are visible in relation to anthropogenic activity, namely the tall grass growing on the archaeological excavations at the main trench, and the berry patch on the main trench. (b) These changes are also visible on30 cm WorldView-03 @Maxar imagery, albeit with much lower resolution. (c) Vegetation differences are very prominent on the false color composite (d) The NDVI raster did not display good contrast between vegetation types, unlike the (e) NDVIre raster and (f) CIg rasters.

\subsection{Uyakmiut (Type 2 Biomes)}

Uyakmiut (Biome Type 2) is a pre-contact winter village near the mouth of Uyak Creek, $4 \mathrm{~km}$ north of Quinhagak, consisting of four abandoned sod structures which are visible on the surface as $1.5 \mathrm{~m}$ high irregular mounds dated to Cal AD 1450 to 1640 (Figures 12 and 13). Uyakmiut is also well documented in local oral history with several families recounting finding artifacts at the site. Today, the site is an important fall hunting ground for ducks and geese and is characterized by poorly drained soil dominated by a single species of grass (Pleasant 1999). Visual inspection of composite imagery of Uyakmiut suggests that the site contains distinct vegetation signatures surrounding known archeological features that are best captured using the CIg index: in Figure 12a, there are noticeable vegetation color differences corresponding to the extent of the recorded features. However, the 
satellite image depicted in Figure $12 \mathrm{~b}$ reveals only minor and indistinct textural differences around the three known structures. The greatest contrast can be seen in the NIR-GreenRed composite raster which highlights vegetation and textural spikes corresponding to the physical extents of the structures. An assessment of the vegetation index rasters also yields surprising results: NDVI is the most established means of highlighting vegetation change across a wide range of disciplines and applications including previously published archeological studies on Kodiak Island [20]. However, in this case, it has failed to form a strong distinction between the vegetation growing on archeological features and the surrounding area. NDVIre was marginally better for this purpose but is also inadequate for showing the extent of the features. Surprisingly, the CIg index, which has never been used for archaeological prospection purposes, has outperformed all other indices from a visual standpoint. The composite NIR-Green-Red image was also effective at highlighting an apparent cluster of fish-processing pits (and associated vegetation patterns) that were not recorded during ground surveys.

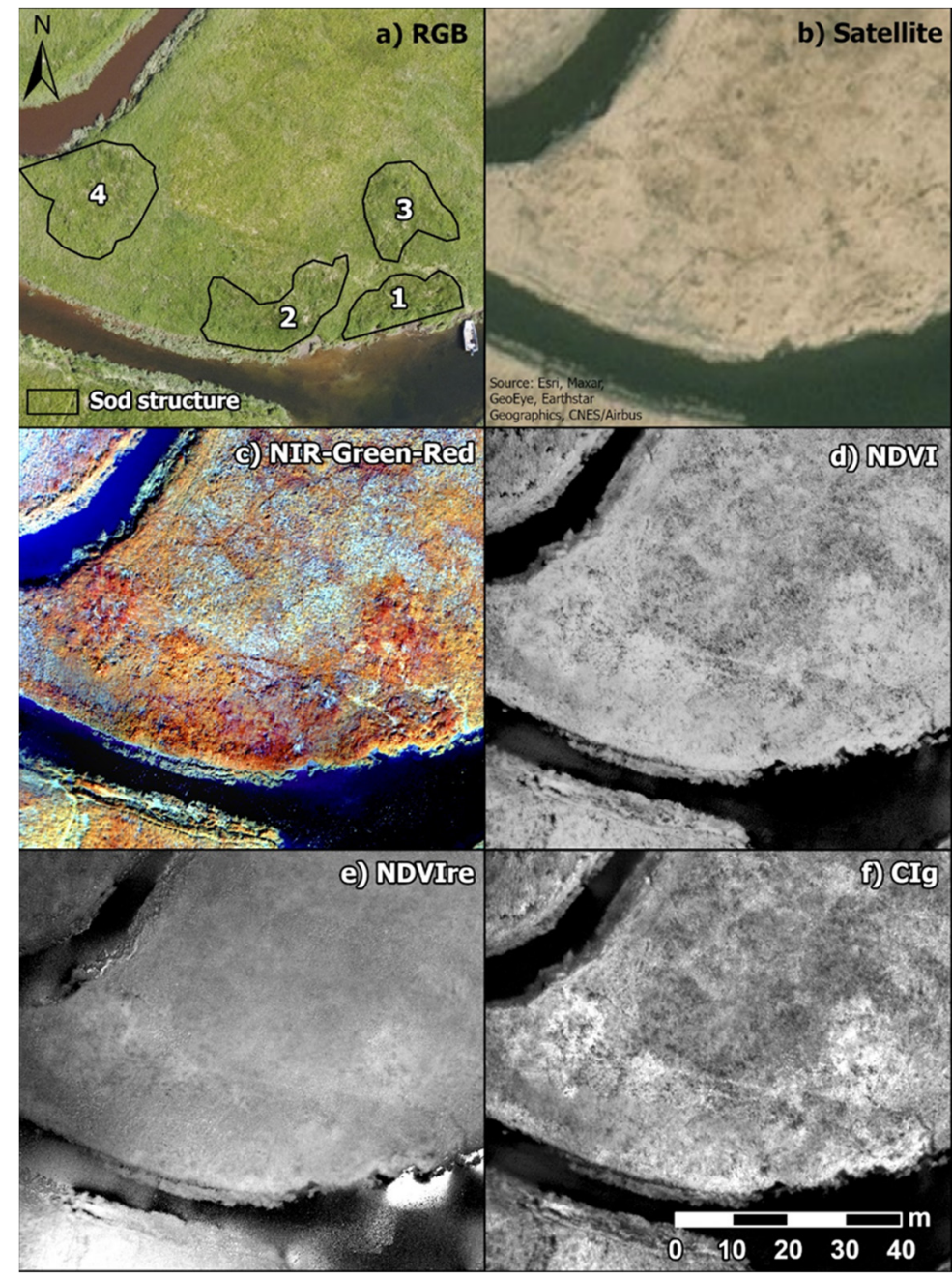

Figure 12. Visualizations of the Uyakmiut site. (a) UAV aerial photograph of the Uyakmiut site, showing location of four abandoned sod houses. (b) However, no structures are visible on $30 \mathrm{~cm}$ WorldView-03 imagery (c) Maxar (c) The composite raster was particularly effective at visually displaying the vegetation patterns associated with the four sod houses. (d) the NDVI raster and (e) NDVIre raster was inadequate for showing vegetation changes around these structures. (f) The Cig raster was highly effective at showing contrast in vegetation on the structures vs. the surroundings. 


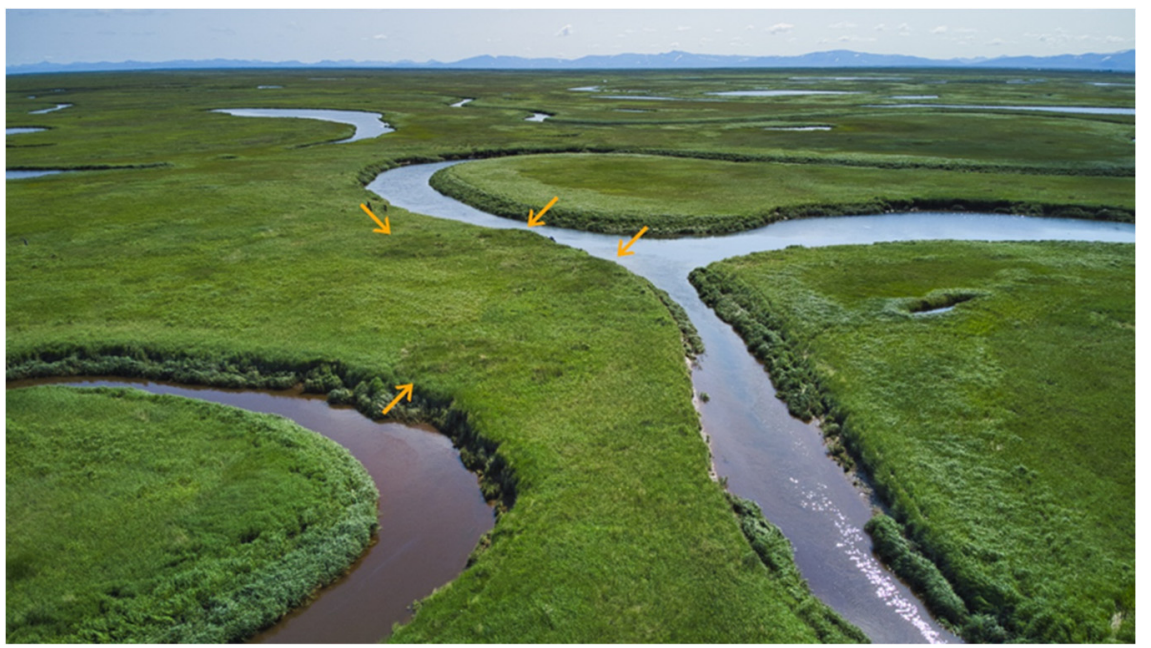

Figure 13. Aerial photograph of the Uyakmiut site facing east. Note the vegetation color changes on the structures.

As evidenced in the PCA graph of the Uyakmiut Green-Red-NIR composite raster, there is a strong, statistically significant clustering of values for each of the vegetation regions measured (Figure 9). The spectral values of the vegetation growing on the sod house and on the apparent fish processing pits ("Pits") are very spatially distinct, despite showing an overlap in values of the area with no known archaeological features (i.e., "Grass"). Here, all indices were successful at distinguishing grass growing on the sod houses, albeit with different results: Inspection of the values of the three vegetation indices tested (Figure 10) confirms that NDVI underperforms in the detection of archeological features in type 2 biomes within Quinhagak's TLUA. Furthermore, the Kruskal-Wallis Test of the NDVI raster values was unable to distinguish between the pit cluster vegetation and the surrounding grass (Table 7). In contrast, NDVIre had very poor visual fidelity when distinguishing vegetation patterns, although it produces the clearest delineation of index values for each area sampled. Finally, CIg shows very little overlap in theIQR between sterile grass and pit cluster grass and was the most successful index for detecting archaeological features within type 2 biomes.

\section{Discussion}

\subsection{Summary of Results}

Visual and statistical classification of each site selected for analysis suggests that spectral data generated from both the visible and non-visible spectrums of light can be captured by UAV-mounted sensors and then processed to accentuate atypical vegetation patterns caused by past human cultural activity. For each biome type, however, different data visualization combinations are needed for effectively defining and characterizing vegetation patterns (Table 7). In most circumstances, the Red-RE-NIR stack combination was most useful for visual inspection. In addition, from a visual standpoint, NDVI was consistently outperformed by the two other vegetation indices tested, especially $\mathrm{Cig}$, which purports to measure chlorophyll content. We are uncertain why this is so-Perhaps, specifically pertaining to the native vegetation on the sites surveyed, the plants show more extreme variability in leaf chlorophyll content than in contexts where NDVI is most effective. For the purpose of quantifying vegetation differences statistically, however, different combinations of raster types seem to work for each biome type (Table 8). In particular, a spectral analysis of the specified composite (PCA) and vegetation index rasters (box plots) yields a very clear signature for anthropogenically derived vegetation change. 
Table 8. Suggested datasets to be generated to analyze vegetation change in sites located in each biome.

\begin{tabular}{cccc}
\hline Biome & $\begin{array}{c}\text { Best Vegetation Index } \\
\text { for Visual Inspection }\end{array}$ & $\begin{array}{c}\text { Best Vegetation Index } \\
\text { for Spectral Analysis }\end{array}$ & $\begin{array}{c}\text { Best Composite Raster } \\
\text { Combination for Spectral Analysis }\end{array}$ \\
\hline $1 \mathrm{a}$ & NDVIre & NDVIre & Red-RE-NIR \\
\hline $1 \mathrm{~b}$ & Cig & Cig & Red-RE-NIR \\
\hline 2 & Cig & NDVIre & Green-Red-NIR \\
\hline
\end{tabular}

\subsection{Deploying UAV-Mounted Sensors for Surveying Cultural Landscapes}

In this study, the coincidence of cultural remains with atypical vegetation growth has been confirmed in the Quinhagak landscape. Furthermore, we have demonstrated how UAV-mounted multispectral imagery, with its very high resolution and ability to measure non-visible light, is particularly suited for this type of survey. At this stage, we can only speculate at what mechanisms are responsible for the atypical vegetation patterns in each biome. They are, however, most likely caused by soil nutrient enrichment, as was noted by Fenger-Nielsen et al. (2019) on similar sites in Greenland [25]. At Tengluk, for instance, soil enrichment and disturbance around former fish processing pits have created statistically significant differences between a community of cilqaaq in the immediate vicinity and the broader species of shrubs located on the terrace edge. Likewise, vegetation patterns at Uyakmiut are equally compelling: a single graminoid species is dominant, and yet two different past human activities (i.e., habitation, and fish processing) have evidently caused the grass here to exhibit two different spectral patterns. Moving forwards, it is crucial to fully understand exactly how past human activity may have caused these patterns, as it may allow easy identification of the past activities having taken place on the site, and even its age since abandonment. This may be accomplished through the chemical analysis of associated soil samples and rigorous absolute dating of any material culture present.

Furthermore, determining if anthropogenically-derived vegetation patterns are statistically comparable between sites of the same biome should be a priority for future research, an aspect that is not possible to address in this study due to the non-functioning of the sunshine sensor.

Our results provide evidence that human-induced changes to ecological landscapes within Quinhagak's TLUA are both visually and statistically distinct from surrounding vegetation. However, the question remains of how these methodologies may be adopted for further landscape monitoring in the Y-K Delta. First, a land cover map of biomes should be created and validated for the study area. Next, multispectral imagery should be obtained and reassessed with all the band and index combinations attempted above to determine if the suggested combinations in Table 8 still apply. If so, Yup'ik communities could leverage specific protocols for the monitoring of known cultural sites associated with Yuuyaraq (Figure 14). Future studies should also consider the role of vegetation community succession based on the age of sites. Although vegetation patterns are visible and quantifiable on satellite imagery of Kodiak Island sites as old as 4000 years BP (Lim et al. 2021), the distinctiveness of atypical vegetation patterns is likely to diminish relative to the age of the site [53]. Here, Quinhagak's TLUA is not sufficient to test this correlation since there are no known sites older than $300 \mathrm{BP}$. 


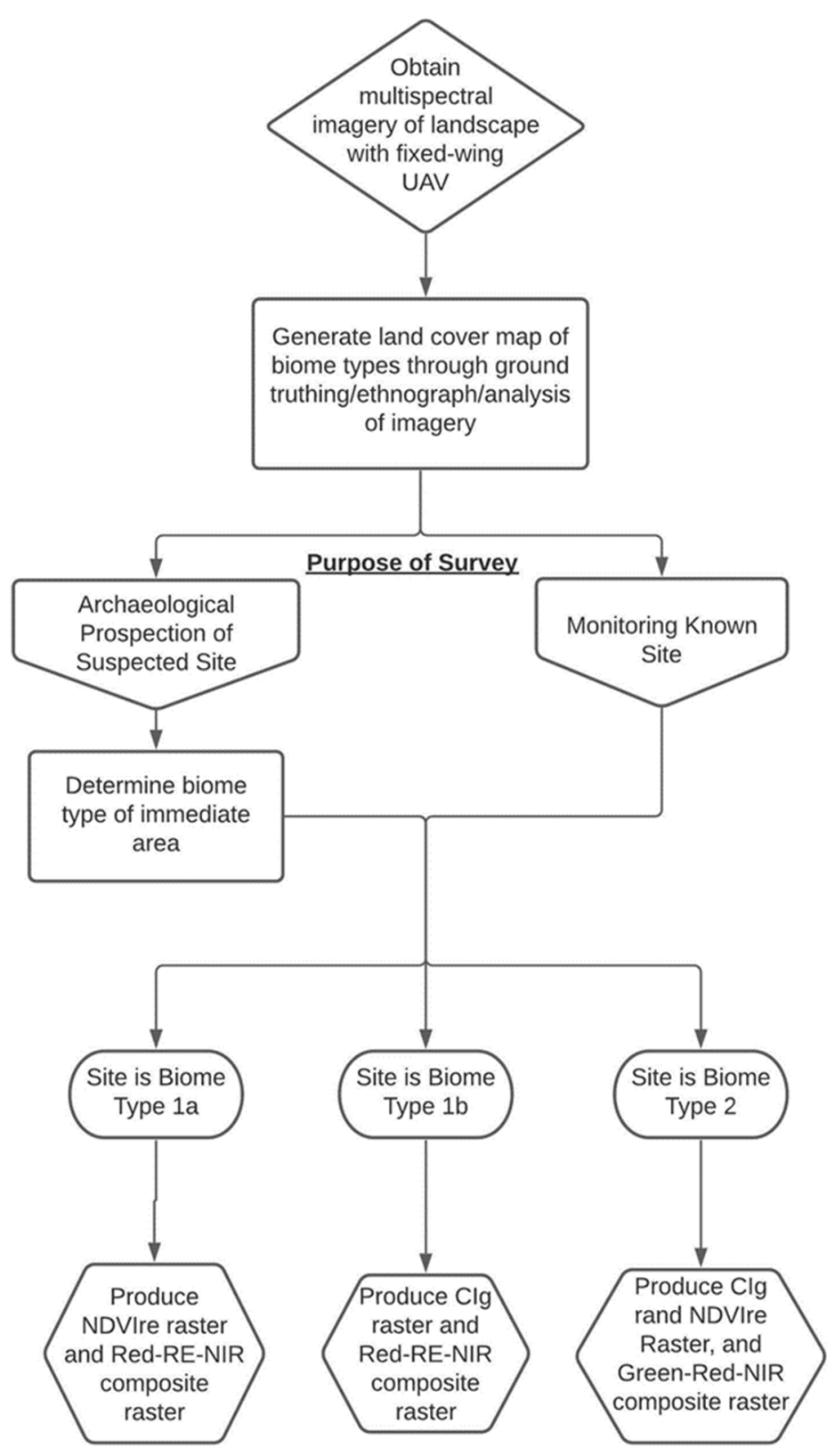

Figure 14. If the assertions made in this study hold true and can be replicated over multiple sites, it enables the creation of a survey protocol like the one suggested here, allowing an operator to easily prospect for sites or monitor known ones.

Perhaps the greatest limitation to our proposed methodology is the low flight time capabilities of most quad-copter UAVs (15-20 min based on wind conditions). Thus, future surveys should make use of larger, fixed wing or Vertical Take Off and Landing (VTOL) UAVs with longer flight times to capture imagery over large swathes of unsurveyed terrain. Another advantage of UAV-based photography that should be leveraged is the ability to use oblique angles to survey the landscape. In Figure 15a, for instance, $30 \mathrm{~cm}$ G.S.D. multispectral imagery is inadequate for visually identifying a large sod structure at GDN267. While this feature is far more visible with the UAV flying at an $80 \mathrm{~m}$ altitude $(\sim 2 \mathrm{~cm}$ G.S.D. Figure 15b), surveying the site at an oblique angle provides more visual clarity and environmental context to the structure (Figure 15c). Perhaps future surveys could make use of UAV video footage shot along areas of interest at oblique angles during periods of optimal lighting. This may be done in a targeted fashion if features are already suspected, or along fixed flight paths where the footage is inspected later for any signs of archaeological 
features. Finally, the use of onboard 'machine vision', wherein the UAV central processing unit (CPU) attempts to automatically identify cultural features should be harnessed for future deployment of UAVs for cultural heritage management [54].

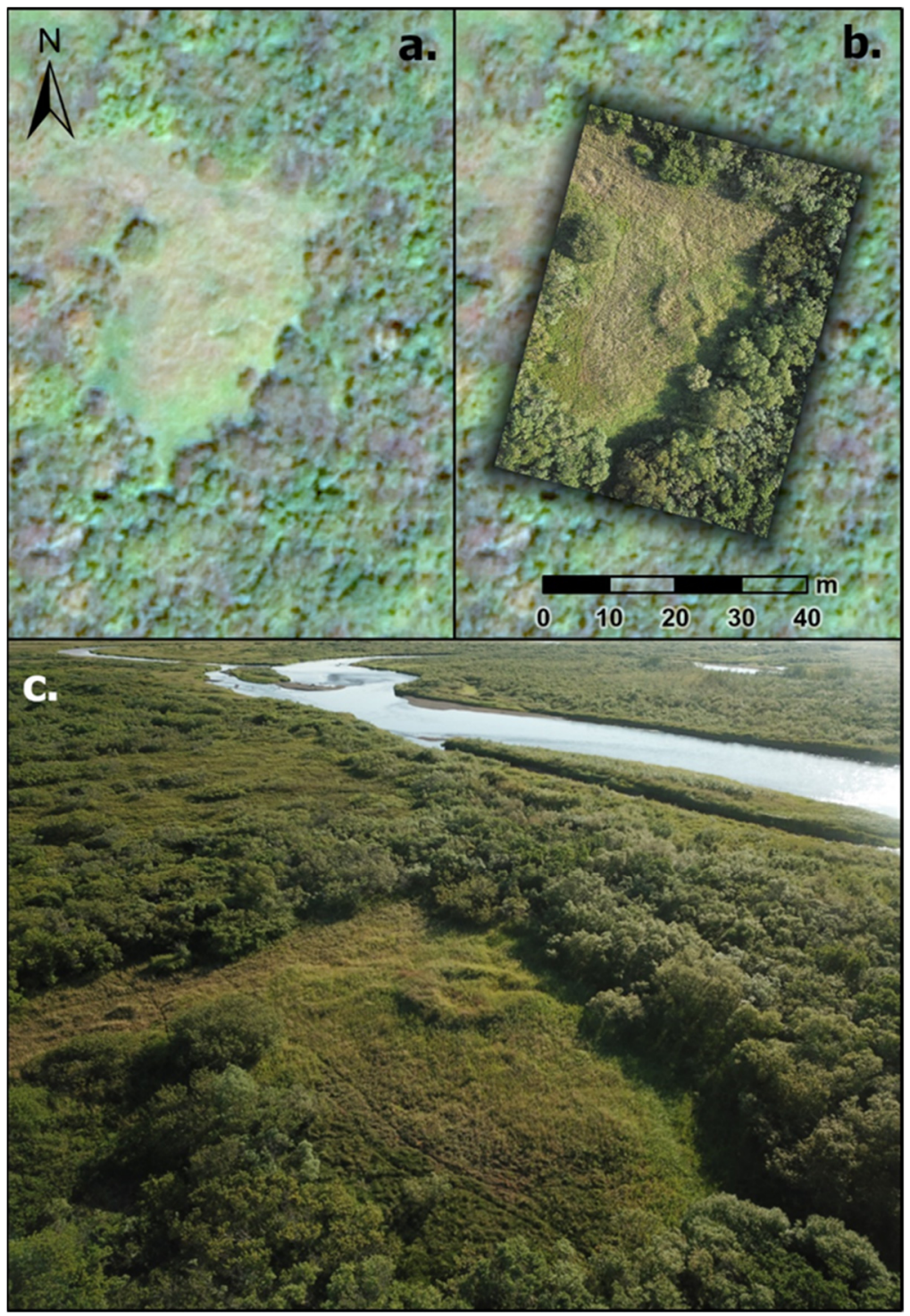

Figure 15. (a) $30 \mathrm{~cm}$ GSD image of the sod structure remains at GDN-267 (b) UAV-based imagery is more capable of characterizing the structure (c) An oblique angle is best for viewing the structure.

\subsection{The Role of Ethnobotany for Augmenting UAV-Based Studies and Monitoring}

The Yukon-Kuskokwim Delta is no stranger to ethnobotanical surveys [41,55], but this is the first time such surveys have been used to help interpret the results of UAV-based remote sensing. At the Nunalleq site, vegetation patterns were defined through ethnobotanical surveys and used to form zones of analysis. Despite the ecological complexity of the site and the relative difficulty of visually distinguishing zones from one another, it is highly encouraging that each zone was statistically distinct-an affirmation of the value of local ecological knowledge. However, the lack of strong clustering of spectral values in the PCA graph of the berry patch on the unexcavated structure is less than ideal, given its dual role as a subsistence resource and an indicator of past human activity. Perhaps more complex techniques are called for-Single Vector Machine pattern recognition has been proven to work in the context of the Y-K Delta [20], and a study is currently underway by the authors to explore if machine learning techniques have a role to play in analyzing UAV imagery. To 
be clear: we do not advocate that remote sensing can replace local knowledge of a landscape. In contrast, remote sensing can complement existing knowledge to quantitatively assess soil and vegetation differences at known sites associated with Yuuyaraq.

In sum, there is enormous potential for Traditional Ecological Knowledge to inform future remote sensing surveys of cultural landscapes in the Y-K Delta beyond archeological features. Although they lack visible indications of exploitation by past and present Yupiit, subsistence camps with no physical cultural remains are no less important for Yuuyaraq. Of the dozens of sites registered on the Alaska Heritage Resource Survey in the vicinity of Quinhagak, all are archaeological sites or historic colonial structures despite calls for inclusion of "Traditional Cultural Properties" (TCP's) that contributes to a community's "historically rooted beliefs, customs, and practices" within the National Register of Historic Places [56]. For instance, the detection of berry patches in the landscape is a high priority: Not only are they a potential indicator of past human activity in Biome $2 b$, but they are one of the primary subsistence foods for Yupiit communities [41]. The ability to identify and monitor berry patches in the landscape is crucial from a cultural subsistence standpoint. Here, the inability of the PCA to strongly delineate berries from the composite raster is disappointing. Further research and refinement are therefore needed to better characterize such sites with UAVs given the importance of subsistence sites as a cultural resource and the fact that these subsistence sites are also impacted by climate change [57].

\section{Conclusions: Automating UAV Data Processing to Build Capacity and Fostering Data Sovereignty}

UAV technological solutions are now viable and cost-effective tools for managing the expansive cultural landscapes of the Y-K Delta. These devices are portable and versatile in terms of their data collection capabilities, as they can be outfitted with specialized sensors for collecting vast amounts of actionable data in a short amount of time. More importantly, when wielded by Alaskan Native heritage stewards, they empower local communities with full control over information flows about their natural environment that they can use to navigate their path through a rapidly changing world. It must also be noted, we are not suggesting that our technology-oriented methodology should replace existing heritage preservation efforts for Yup'ik cultural landscapes. After all, Native Alaskan communities have made enormous progress towards reclaiming their language and traditions with minimal outside assistance $[11,58,59]$. Rather, our proposed UAV remote sensing-based methodology is another tool in their belt they can use to complement their existing protocols and initiatives in the face of the considerable 21st-century threats.

There are increasing calls for Native American groups to exert more control over their ancestral ecological resources and retain full ownership of all data derived from research on Indigenous lands, both in Alaska [39] and elsewhere in North America [60,61]. Providing Alaskan Native administrative entities access to UAVs would facilitate this process by generating proprietary spatial data rather than satellite imagery since satellite-derived data entails restrictions on data use. In most cases, imagery purchased from geospatial companies is not owned by the customer but licensed for use for a singular purpose and may not be disseminated or reproduced without the consent of the satellite operators. There is also no guarantee that geospatial companies will have suitable images in their archives, or that they will be able to task a satellite to capture new imagery in a timely and affordable manner. With access to a UAV outfitted with suitable sensors, Alaskan Native communities will be able to capture imagery whenever and wherever they want to manage their cultural landscapes and have full control over the data they produce. It also enables long-term longitudinal studies, allowing communities to monitor environmental impacts on heritage to help plan for an uncertain future.

The greatest strength of the methodological processes outlined in this study may be easily organized into a streamlined workflow. By automating a series of geospatial tools needed to process the data, an operator with minimal training may replicate the methodology of this study through a series of predefined steps, adjusting only a few 
parameters each time (Figure 16. Example scripts available for download below). This enables the swift training of Alaskan Native geospatial operators, a necessity in this age of impending climate-change-related threats to local cultural heritage.

\section{Example Automated Workflow For Processing and Analyzing UAV Imagery of a Heritage Site}

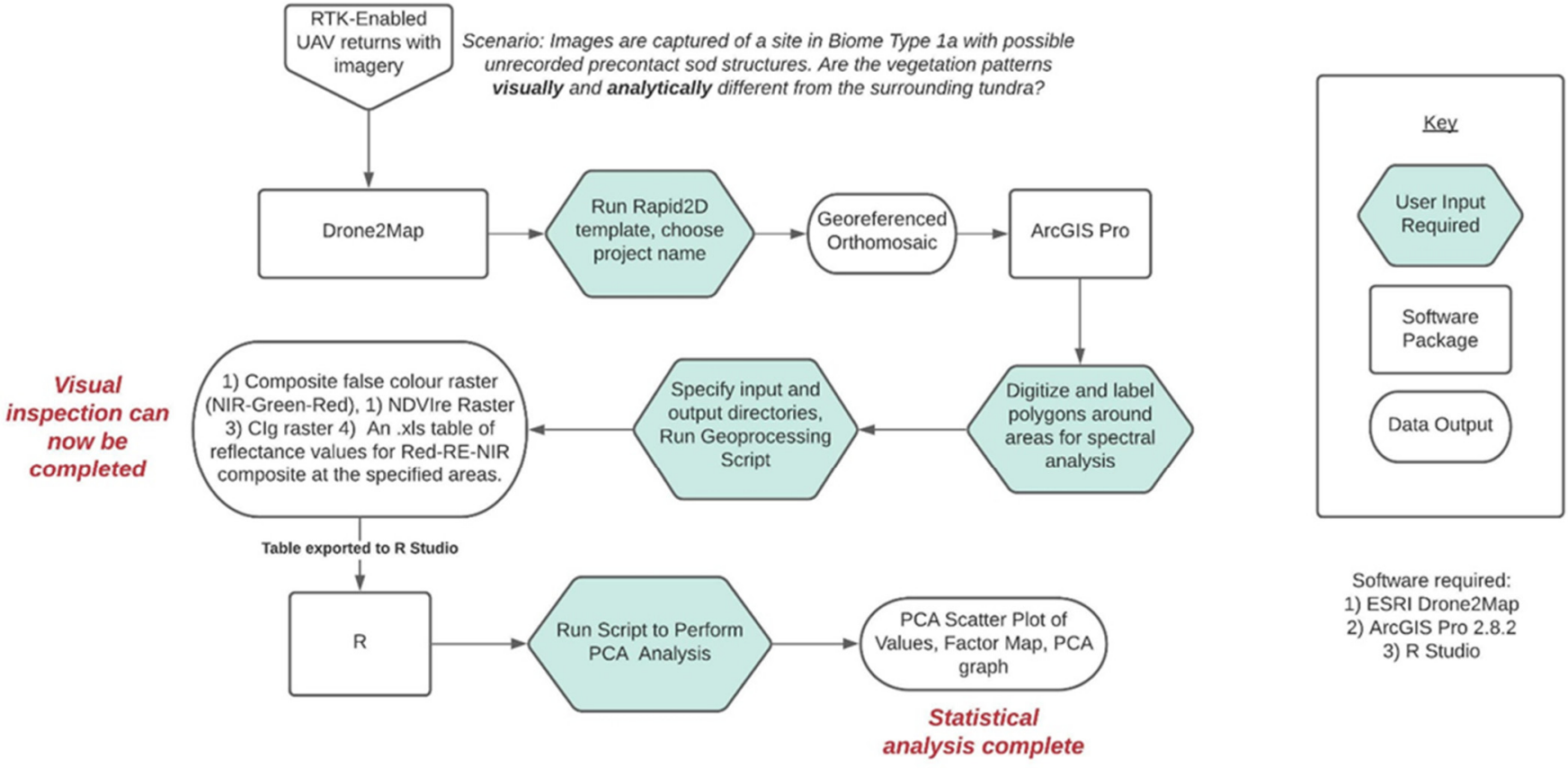

Figure 16. Example of an automated UAV workflow for capturing environmental data for heritage management. It only requires user input at four key places throughout the whole process, potentially saving the user dozens of manual steps.

Author Contributions: Conceptualization J.S.L. and S.G.; methodology, J.S.L., S.G. and M.W.; software, J.S.L., S.G. and G.J.L.M.; validation, J.S.L., S.G. and G.J.L.M.; formal analysis, J.S.L. and S.G.; investigation, J.S.L., S.G., M.W., G.J.L.M. and D.M.; resources, J.S.L., S.G., D.M. and W.J.; data curation, J.S.L., S.G. and W.J.; writing-original draft preparation, J.S.L., S.G. and G.J.L.M.; writing-review and editing, J.S.L., S.G., M.W., G.J.L.M. and D.M.; visualization, J.S.L. and G.J.L.M.; supervision, S.G. and W.J.; project administration, S.G. and W.J.; funding acquisition, J.S.L., S.G. and W.J. All authors have read and agreed to the published version of the manuscript.

Funding: The research costs of J.S.L. were funded by an Emslie Horniman Scholarship provided by the Royal Anthropological Institute/Sutasoma Trust, a Heritage Seed Fund (0008440) grant from The Oxford Research Center for the Humanities, and a Meyerstein research grant from the School of Archaeology, University of Oxford. The research costs of S.G. were funded by the Virginia Foundation for Independent Colleges (VFIC), Hampden-Sydney College, and Quinhagak Heritage Incorporated (QHI). The research of G.J.L.M. was supported by the Arts and Humanities Research Council [Grant number AH/R012709/1] as a Baillie Gifford AHRC Scholarship (OOC-DTP program) for his DPhil in Archaeology at St. Hugh's College, University of Oxford.

Institutional Review Board Statement: The study was conducted in accordance with the Declaration of Helsinki, and approved by the Social Sciences Ethics Committee of the University of Oxford (R70667/RE001), and of Hampden-Sydney College as IRB exempt on 18 March 2021.

Informed Consent Statement: Informed consent was obtained from all subjects involved in the study in conjunction with Qanirtuuq Inc and Quinhagak Heritage Inc. 
Data Availability Statement: Data available on request due to restrictions (e.g., privacy or ethical). The data presented in this study are available on request from the corresponding author, with additional prior permission from Warren Jones (wjones@qanirtuuq.com) of Qanirtuuq Incorporated. The data are not publicly available due to being owned by the community of Quinhagak, as represented by Qanirtuuq Incorporated.

Acknowledgments: We are indebted to the community of Quinhagak—especially Joseph Pleasant, Willard Church, Jessica Alexie, John Foster, and John Smith-for their friendship, support, and for allowing us to carry out this research on their lands. This project would not have been possible without the generous support of Linda McDowell. We are also grateful to the members and volunteers of the Quinhagak Archaeological Project, particularly Rick Knecht of the University of Aberdeen and Anna Mossolova. We thank the academic supervisors of J.L., Rick Schulting and John Pouncett (School of Archaeology, University of Oxford) for their advice and feedback in the preparation of this article. Deepest thanks to Anne Fienup-Riordan for permission to reproduce the photograph in Figure 8. Thanks also to Izac Mercer (Hampden-Sydney College) for assistance with proofreading. We are also grateful to our four anonymous reviewers, whose comments and feedback greatly improved the quality of this article.

Conflicts of Interest: The authors declare no conflict of interest.

\section{References}

1. Jorgenson, M.T.; Frost, G.V.; Dissing, D. Drivers of Landscape Changes in Coastal Ecosystems on the Yukon-Kuskokwim Delta, Alaska. Remote Sens. 2018, 10, 1280. [CrossRef]

2. Rearden, A.; Fienup-Riordan, A. Erinaput Unguvaniartut: So Our Voices Will Live: Quinhagak History and Oral Traditions; Alaska Native Language Center: Fairbanks, AK, USA, 2013; ISBN 978-0-615-86633-8.

3. Fienup-Riordan, A.; Rearden, A.; Knecht, M. Irr'inarqellriit/Amazing Things: Quinhagak Elders Reflect on Their Past. Alsk. J. Anthropol. 2015, 13, 37-70.

4. Cochran, P.; Huntington, O.H.; Pungowiyi, C.; Tom, S.; Chapin, F.S., III; Huntington, H.P.; Maynard, N.G.; Trainor, S.F. Indigenous Frameworks for Observing and Responding to Climate Change in Alaska. Clim. Chang. 2013, 120, 557-567. [CrossRef]

5. Britton, K.; Hillerdal, C. Archaeologies of Climate Change: Perceptions and Prospects. Études Inuit Stud. 2019, 43, 265-287. [CrossRef]

6. Hollesen, J.; Callanan, M.; Dawson, T.; Fenger-Nielsen, R.; Friesen, T.M.; Jensen, A.M.; Markham, A.; Martens, V.V.; Pitulko, V.V.; Rockman, M. Climate change and the deteriorating archaeological and environmental archives of the Arctic. Antiquity 2018, 92, 573-586. [CrossRef]

7. Terenzi, J.; Jorgenson, M.T.; Ely, C.R.; Giguère, N. Storm-Surge Flooding on the Yukon-Kuskokwim Delta, Alaska. Arctic 2014, 67, 360-374. [CrossRef]

8. Bronen, R. Forced Migration of Alaskan Indigenous Communities Due to Climate Change. In Environment, Forced Migration and Social Vulnerability; Afifi, T., Jäger, J., Eds.; Springer: Berlin/Heidelberg, Germany, 2010; pp. 87-98. ISBN 978-3-642-12416-7.

9. Fienup-Riordan, A. The Way We Genuinely Live; University of Washington Press: Seattle, WA, USA, 2007; ISBN 978-0-295-98669-2.

10. Hillerdal, C.; Knecht, R.; Jones, W. Nunalleq: Archaeology, Climate Change, and Community Engagement in a Yup'ik Village. Arct. Anthropol. 2019, 56, 4-17. [CrossRef]

11. Knecht, R.; Jones, W. "The Old Village": Yup'ik Precontact Archaeology and Community-Based Research at the Nunalleq Site, Quinhagak, Alaska. Études Inuit Stud. 2019, 43, 25-52. [CrossRef]

12. Steffian, A.; Leist, M.; Haakanson, S.; Saltonstall, P. Kal'unek/From Karluk: Kodiak Alutiiq History and the Archaeology of the Karluk One Village Site; Illustrated Edition; University of Alaska Press: Fairbanks, AK, USA, 2015; ISBN 978-1-60223-244-0.

13. Fienup-Riordan, A. (Ed.) Qaluyaarmiuni Nunamtenek Qanemciput/Our Nelson Island Stories: Meanings of Place on the Bering Sea Coast; Illustrated Edition; University of Washington Press: Bethel, NY, USA, 2011; ISBN 978-0-295-99135-1.

14. Herman-Mercer, N.M.; Matkin, E.; Laituri, M.J.; Toohey, R.C.; Massey, M.; Elder, K.; Schuster, P.F.; Mutter, E.A. Changing Times, Changing Stories: Generational Differences in Climate Change Perspectives from Four Remote Indigenous Communities in Subarctic Alaska. Ecol. Soc. 2016, 21, 28. [CrossRef]

15. Smith, J.; Gleason, S. "Knowledge Is Like Food": Qanruyutet on Change and Subsistence from John Smith. Text Perform. Q. 2021, 41,37-60. [CrossRef]

16. Khorram, S.; Koch, F.H.; van der Wiele, C.F.; Nelson, S.A.C. Remote Sensing; Springer Briefs in Space Development; Springer: New York, NY, USA, 2012; ISBN 978-1-4614-3102-2.

17. Keeney, J.; Hickey, R. Using Satellite Image Analysis for Locating Prehistoric Archaeological Sites in Alaska's Central Brooks Range. J. Archaeol. Sci. Rep. 2015, 3, 80-89. [CrossRef]

18. Linares Matás, G.J.; Lim, J.S. Monumental Funerary Landscapes of Dhar Tagant (South-Eastern Mauritania): Towards Ethical Satellite Remote Sensing in the West African Sahel. Archaeol. Prospect. 2021, 28, 357-378. [CrossRef] 
19. Davis, D.S.; Andriankaja, V.; Carnat, T.L.; Chrisostome, Z.M.; Colombe, C.; Fenomanana, F.; Hubertine, L.; Justome, R.; Lahiniriko, F.; Léonce, H.; et al. Satellite-Based Remote Sensing Rapidly Reveals Extensive Record of Holocene Coastal Settlement on Madagascar. J. Archaeol. Sci. 2020, 115, 105097. [CrossRef]

20. Lim, J.S.; Gleason, S.; Jones, W.; Church, W. Nuna Nalluyuituq (The Land Remembers): Remembering Landscapes and Refining Methodologies through Community-Based Remote Sensing in the Yukon-Kuskokwim Delta, Southwest Alaska. Archaeol. Prospect. 2021, 28, 339-355. [CrossRef]

21. Fisher, M.; Fradley, M.; Flohr, P.; Rouhani, B.; Simi, F. Ethical Considerations for Remote Sensing and Open Data in Relation to the Endangered Archaeology in the Middle East and North Africa Project. Archaeol. Prospect. 2021, 28, 279-292. [CrossRef]

22. Beamish, A.; Raynolds, M.K.; Epstein, H.; Frost, G.V.; Macander, M.J.; Bergstedt, H.; Bartsch, A.; Kruse, S.; Miles, V.; Tanis, C.M.; et al. Recent Trends and Remaining Challenges for Optical Remote Sensing of Arctic Tundra Vegetation: A Review and Outlook. Remote Sens. Environ. 2020, 246, 111872. [CrossRef]

23. Avtar, R.; Watanabe, T. Introduction. In Unmanned Aerial Vehicle: Applications in Agriculture and Environment; Avtar, R., Watanabe, T., Eds.; Springer: Cham, Switzerland, 2020; pp. 1-7.

24. Harmsen, H.; Hollesen, J.; Madsen, C.K.; Albrechtsen, B.; Myrup, M.; Matthiesen, H. A Ticking Clock? Preservation and Management of Greenland's Archaeological Heritage in the Twenty-First Century. Conserv. Manag. Archaeol. Sites 2018, 20, 175-198. [CrossRef]

25. Fenger-Nielsen, R.; Hollesen, J.; Matthiesen, H.; Andersen, E.A.S.; Westergaard-Nielsen, A.; Harmsen, H.; Michelsen, A.; Elberling, B. Footprints from the Past: The Influence of Past Human Activities on Vegetation and Soil across Five Archaeological Sites in Greenland. Sci. Total Environ. 2019, 654, 895-905. [CrossRef]

26. Walker, S. Low-Altitude Aerial Thermography for the Archaeological Investigation of Arctic Landscapes. J. Archaeol. Sci. 2020, 117, 105126. [CrossRef]

27. Walsh, M.J.; Tejsner, P.; Carlson, D.F.; Vergeynst, L.; Kjeldsen, K.U.; Gründger, F.; Dai, H.; Thomsen, S.; Laursen, E. The VIMOA Project and Archaeological Heritage in the Nuussuaq Peninsula of North-West Greenland. Antiquity 2020, 94, E6. [CrossRef]

28. Nicu, I.C.; Rubensdotter, L.; Stalsberg, K.; Nau, E. Coastal Erosion of Arctic Cultural Heritage in Danger: A Case Study from Svalbard, Norway. Water 2021, 13, 784. [CrossRef]

29. Liu, J.; Chen, J.; Qin, Q.; You, H.; Han, X.; Zhou, G. Patch Pattern and Ecological Risk Assessment of Alpine Grassland in the Source Region of the Yellow River. Remote Sens. 2020, 12, 3460. [CrossRef]

30. Lasaponara, R.; Masini, N. Detection of Archaeological Crop Marks by Using Satellite QuickBird Multispectral Imagery. J. Archaeol. Sci. 2007, 34, 214-221. [CrossRef]

31. Boles, O.J.C.; Lane, P.J. The Green, Green Grass of Home: An Archaeo-Ecological Approach to Pastoralist Settlement in Central Kenya. Azania Archaeol. Res. Afr. 2016, 51, 507-530. [CrossRef]

32. Lyons, N.; Ritchie, M. The Archaeology of Camas Production and Exchange on the Northwest Coast: With Evidence from a Sts'ailes (Chehalis) Village on the Harrison River, British Columbia. J. Ethnobiol. 2017, 37, 346-367. [CrossRef]

33. O'Rourke, S.R.; Turner, J.J.; Ritchie, K. Key to the Past: Community Perceptions of Yup'ik Youth Interaction with Culturally Relevant Education Inspired by the Nunalleq Archaeology Project. J. Archaeol. Educ. 2018, 2, 1.

34. Milek, K. Transdisciplinary Archaeology and the Future of Archaeological Practice: Citizen Science, Portable Science, Ethical Science. Nor. Archaeol. Rev. 2018, 51, 36-47. [CrossRef]

35. Mossolova, A. Innovation and Healing in Contemporary Yup'ik Mask Making. Anthropologica 2020, 62, 365-379. [CrossRef]

36. Linares Matás, G.J.; Lim, J.S. “This Is the Way": Knowledge Networks and Toolkit Specialization in the Circumpolar Coastal Landscapes of Western Alaska and Tierra Del Fuego. J. Isl. Coast. Archaeol. 2021, 1-29. [CrossRef]

37. Lim, J.S.; Matás, G.J.L. Using Open Spatial Data to Investigate the Importance of Salmon Streams in the Indigenous Cultural Landscapes of Southwest Alaska. SocArXiv 2021, 1-25. [CrossRef]

38. Pleasant, J. Traditional Names and Places of Native Village of Kwinhagak; Native Village of Kwinhagak, Quinhagak IRA Council: Quinhagak, AK, USA, 1999.

39. Hanson, D.K. Cultural Resource Management in Alaska. Alsk. J. Anthropol. 2007, 5, 1-16.

40. Yugtun. Available online: https://www.yugtun.com/ (accessed on 28 December 2021).

41. Fienup-Riordan, A. Yungcautnguuq Nunam Qainga Tamarmi/The Entire Surface of the Land Is Medicine: Edible and Medicinal Plants of Southwest Alaska; University of Alaska Press: Fairbanks, AK, USA, 2021; ISBN 978-1-60223-422-2.

42. Tucker, C.J. Red and Photographic Infrared Linear Combinations for Monitoring Vegetation. Remote Sens. Environ. 1979, 8, 127-150. [CrossRef]

43. Barnes, E.M.; Clarke, T.R.; Richards, S.E.; Colaizzi, P.D.; Haberland, J.; Kostrzewski, M.; Waller, P.; Choi, C.; Riley, E.; Thompson, T. Coincident Detection of Crop Water Stress, Nitrogen Status and Canopy Density Using Ground-Based Multispectral Data. In Proceedings of the 5th International Conference on Precision Agriculture and Other Resource Management, Bloomington, MN, USA, 16-19 July 2000.

44. Muramatsu, K. Use of Chlorophyll Index-Green and the Red-Edge Chlorophyll Index to Derive an Algorithm for Estimating Gross Primary Production Capacity. In Proceedings of the Conference on Remote Sensing for Agriculture, Ecosystems, and Hydrology XXI, Strasbourg, France, 9-11 September 2019; SPIE: Bellingham, WA, USA, 2019; Volume 11149, pp. 54-61.

45. Everitt, B.S.; Skrondal, A. The Cambridge Dictionary of Statistics, 4th ed.; Cambridge University Press: Cambridge, UK; New York, NY, USA, 2010; ISBN 978-0-521-76699-9. 
46. Lê, S.; Josse, J.; Husson, F. FactoMineR: An R Package for Multivariate Analysis. J. Stat. Softw. 2008, 25, 1-18. [CrossRef]

47. Pearson, K. LIII. On Lines and Planes of Closest Fit to Systems of Points in Space. Lond. Edinb. Dublin Philos. Mag. J. Sci. 1901, 2, 559-572. [CrossRef]

48. Hotelling, H. Analysis of a Complex of Statistical Variables into Principal Components. J. Educ. Psychol. 1933, $24,417-441$. [CrossRef]

49. Tang, Y.; Horikoshi, M.; Li, W. Ggfortify: Unified Interface to Visualize Statistical Results of Popular R Packages. R J. 2016, 8, 474-485. [CrossRef]

50. Fisher, R.A. The Precision of Discriminant Functions. Ann. Eugen. 1940, 10, 422-429. [CrossRef]

51. McLachlan, G.J. Discriminant Analysis and Statistical Pattern Recognition; John Wiley \& Sons: Hoboken, NJ, USA, 2005; ISBN 978-0-471-72528-2.

52. Venables, W.N.; Ripley, B.D. Modern Applied Statistics with S-Plus; Springer Science \& Bussines Media: Berlin/Heidelberg, Germany, 1999.

53. Lane, P.J. Entangled Banks and the Domestication of East African Pastoralist Landscapes. In Archaeology of Entanglement; Routledge: Abingdon-on-Thames, UK, 2016; ISBN 978-1-315-43393-6.

54. Chowdhery, A.; Chiang, M. Model Predictive Compression for Drone Video Analytics. In Proceedings of the 2018 IEEE International Conference on Sensing, Communication and Networking (SECON Workshops), Hong Kong, China, 11-13 June 2018; pp. 1-5.

55. Ager, T.A.; Ager, L.P. Ethnobotany of the Eskimos of Nelson Island, Alaska. Arct. Anthropol. 1980, 17, $26-48$.

56. Parker, P.; King, T.F. Guidelines for Evaluating and Documenting Traditional Cultural Properties; U.S. Department of the Interior, National Park Service, Interagency Resources Division: Washington, DC, USA, 1990.

57. Herman-Mercer, N.M.; Loehman, R.A.; Toohey, R.C.; Paniyak, C. Climate- and Disturbance-Driven Changes in Subsistence Berries in Coastal Alaska: Indigenous Knowledge to Inform Ecological Inference. Hum. Ecol. 2020, 48, 85-99. [CrossRef]

58. Barnhardt, N.R. Creating a place for indigenous knowledge in education: The Alaska native knowledge network. In Place-Based Education in the Global Age; Routledge: Abingdon-on-Thames, UK, 2007; ISBN 978-1-315-76984-4.

59. Charles, W. Qaneryaramta Egmiucia: Continuing Our Language. Anthropol. Educ. Q. 2005, 36, 107-111. [CrossRef]

60. Harding, A.; Harper, B.; Stone, D.; O'Neill, C.; Berger, P.; Harris, S.; Donatuto, J. Conducting Research with Tribal Communities: Sovereignty, Ethics, and Data-Sharing Issues. Environ. Health Perspect. 2012, 120, 6-10. [CrossRef] [PubMed]

61. Latulippe, N.; Klenk, N. Making Room and Moving over: Knowledge Co-Production, Indigenous Knowledge Sovereignty and the Politics of Global Environmental Change Decision-Making. Curr. Opin. Environ. Sustain. 2020, 42, 7-14. [CrossRef] 